\title{
Heat source of the 2014 phreatic eruption of Mount Ontake, Japan
}

\author{
Isoji Miyagi ${ }^{1}(\mathbb{D}) \cdot$ Nobuo Geshi $^{1} \cdot$ Satoshi Hamasaki ${ }^{1} \cdot$ Teruki Oikawa $^{1} \cdot$ Akihiko Tomiya $^{1}$
}

Received: 9 July 2019 / Accepted: 9 January 2020 / Published online: 4 March 2020

(C) The Author(s) 2020

\begin{abstract}
We present petrological evidence of the shallow magmatic processes that may have supplied heat and gas to the eruption of Mount Ontake, Japan, on 27 September 2014, which resulted in 63 fatalities. Ash from the eruption comprises primarily hydrothermally altered, white-toned rock fragments. However, the ash contains trace amounts $(<0.7 \mathrm{wt} \%)$ of vitreous lessaltered particles (LAPs), which are only altered on their surfaces, suggesting rapid ascent through the hydrothermal system. The LAPs are classified into two categories: "glassy" and "crystalline." Glassy LAPs comprise high-silica rhyolitic glass (74-83 wt\% $\mathrm{SiO}_{2}$ ) with rounded quartz, chalcedony-free vesicles, and reversely zoned plagioclase (cores $=47 \mathrm{~mol} \% \mathrm{An} ; \operatorname{rims}=70 \mathrm{~mol} \%$ An), indicating magma re-heating. Crystalline LAPs have a groundmass-like texture that suggests eutectic crystallization at shallow depths. Thermodynamic calculations indicate that the pre-eruptive temperatures of the glassy and crystalline LAPs were $700-1300^{\circ} \mathrm{C}$ and $\sim 700{ }^{\circ} \mathrm{C}$, respectively, and that the storage depth was $<4 \mathrm{~km}$ (pressure $<100 \mathrm{MPa}$ ). The observed petrological features suggest that the LAPs were sourced from a magma recently intruded at shallow depths. Although crustal deformation (i.e., the volume change associated with magmatic intrusion) was insignificant prior to the 2014 eruption, a clear signature of crustal deformation was observed in 2007, the source of which was located $3 \mathrm{~km}$ below the summit. We suggest that the magma that was intruded $3 \mathrm{~km}$ below the summit in 2007 supplied the heat and gas for the 2014 phreatic eruption.
\end{abstract}

Keywords Phreatic eruption $\cdot$ Hydrothermal system $\cdot$ Shallow magmatic intrusion $\cdot$ Less-altered particles $\cdot$ Ash texture $\cdot$ MELTS

\section{Introduction}

Phreatic eruptions are relevant to volcanic hazard because they frequently occur with respect to large magmatic eruptions, and can occur suddenly without obvious precursory phenomena (Barberi et al., 1992; Bruce, 2002). The beautiful scenery of volcanoes can attract many tourists who can venture close to the summit area during pauses in activity (cf. ErfurtCooper and Cooper, 2010). Even if a phreatic eruption is relatively small in terms of its energy, it still has the ability to eject blocks with sufficient kinetic energy to cause fatalities close to

Editorial responsibility: L. Pioli

Electronic supplementary material The online version of this article (https://doi.org/10.1007/s00445-020-1358-x) contains supplementary material, which is available to authorized users.

Isoji Miyagi

miyagi.iso14000@aist.go.jp

1 Geological Survey of Japan, AIST, 1-1-1-7 Higashi, Tsukuba, Ibaraki 305-8567, Japan the vent zone as shown by the 1994 Rabaul eruption (Bruce, 2002), by the 2019 White Island eruption, and by the 2014 Mount Ontake eruption. During this event, numerous volcanic blocks were ejected to land within $\sim 1 \mathrm{~km}$ of the craters (Oikawa et al., 2015). The kinetic energy of the ballistic ejecta has been estimated to be $\sim 4.2 \times 10^{4} \mathrm{~J}$ (Tsunematsu et al., 2016) and 63 fatalities amongst tourists who were visiting the volcano summit at the time of the eruption resulted. In addition, phreatic eruptions sometimes produce base surge flows, in which turbulent mixtures of steam and solid ejecta flow outward from the crater at high velocities (Fischer and Waters, 1970). Understanding the mechanism of, and surveillance of, phreatic eruptions will thus contribute to hazard mitigation.

The current understanding of the mechanisms of phreatic eruptions, however, is not good enough to be applied to eruption monitoring. Phreatic eruptions are related to rock fracture phenomena, and hydrothermal eruptions are sometimes triggered by earthquakes that create fractures cutting hydrothermal aquifers beneath the eruption site (Marini et al., 1993). Large-scale deformation of the volcanic edifice is also known to trigger phreatic eruptions either with (Bezymianny type) or without (Bandai type) a magmatic input (Siebert et al., 1987). 
Hydrothermal alteration processes can also increase porosity and permeability, and reduce rock strength, leading to phreatic eruptions (Mayer et al., 2016). However, it is generally difficult to predict when and where such rock fracturing will trigger an eruption.

Magmatic eruptions are driven by magmatic gases and mainly emit magma fragments (Cas and Wright, 1987; Papale and Dobran, 1993; Sigurdsson et al., 1982), along with fragments of host rocks eroded from the conduit (Fig. 1(a)). Instead, phreatomagmatic eruptions involve magma reactions with external water (Cas and Wright, 1987; Sheridan and Wohletz, 1981, 1983). In this case, the eruption is driven not only by magmatic gases but also by the external water that expands due to magmatic heating. The resulting steam generation and expansion produce a large amount of gas and results in significant fragmentation of the host rock around the conduit (Barberi et al., 1989). As a result, the ejecta is sometimes composed mainly of host rock fragments (Schmincke, 2004), but will also include magma fragments (Fig. 1(b)). Phreatomagmatic eruptions are often observed during the closing periods of basaltic eruptions when the magma in the conduit withdraws, promoting the rapid interaction of magma and in-flowing external water, a process which also requires a sufficient magma surface area to be exposed to the interaction, this being a requirement to achieve the high rates of heat transfer necessary to generate the explosion (Lorenz, 1987; Mattox and Mangan, 1997; McPhie et al., 1990; Oh and

\section{Magmatic eruption}
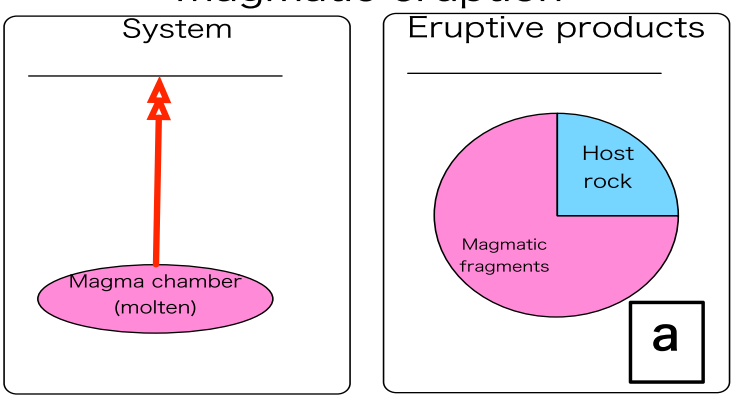

Phreatic eruption
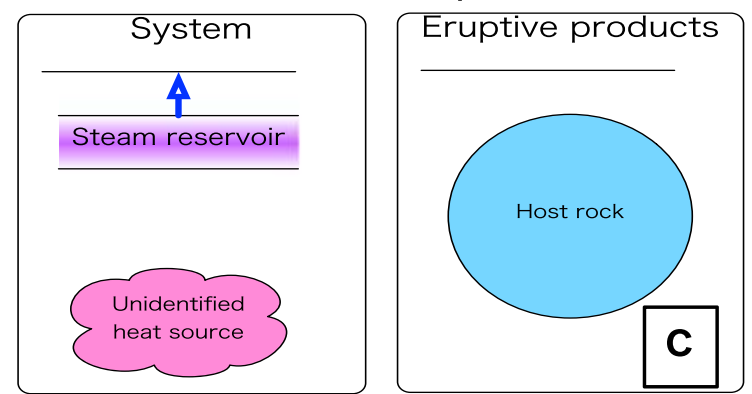

Fig. 1 Eruption styles and nature of the erupted materials. Schematic system diagrams show the cases for (a) magmatic, (b) phreatomagmatic, (c) phreatic, and (d) 2014 Ontake eruptions. The red arrow line represents
Corradini, 1987; White, 1996; Wohletz, 1986; Yamamoto et al., 1991; Zimanowski et al., 1991).

Phreatic eruptions (steam eruptions) produce significant proportions of country-rock fragments (Cas and Wright, 1987), from which driven by underground steam that generated by some heat source, where magmatic processes are not the principal driving mechanism (Stix and de Moor, 2018). Although a broadly accepted classification scheme of phreatic eruption is lacking (Stix and de Moor, 2018), the heat source in most cases is magma (Fig. 1(c)). Given that the magma does not directly contribute to the eruption, the eruptive products consist only of host rock fragments and do not contain magma fragments (i.e., no juvenile magmatic material) (Fig. 1(c)). Since a phreatic eruption does not require direct interaction of magma and water (e.g., Germanovich and Lowell, 1995; Hedenquist and Henley, 1985; Lloyd, 1959; Mastin, 1995; Mayer et al., 2015; Montanaro et al., 2016; Ohba et al., 2007), many phreatic eruptions occur without clear precursory events such as deformation and seismicity associated with magma ascent. However, a physical model of rock fracturing (Germanovich and Lowell, 1995) suggested that geophysical precursors, such as anomalous seismicity, ground deformation, and changes in fumarolic and hot spring output, could be detected before phreatic eruptions (de Moor et al., 2016).

In summary, it is the energy of high-pressure gas that drives all the types of eruption mentioned above (Fig. 1). In the case of magmatic and phreatomagmatic eruptions,

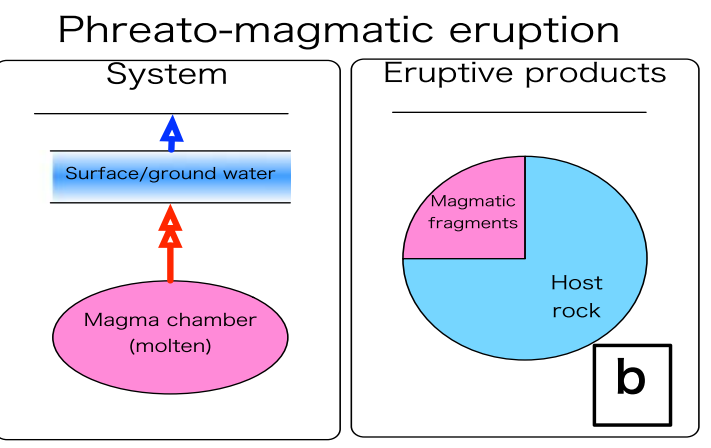

The case where the hidden heat source jumped out

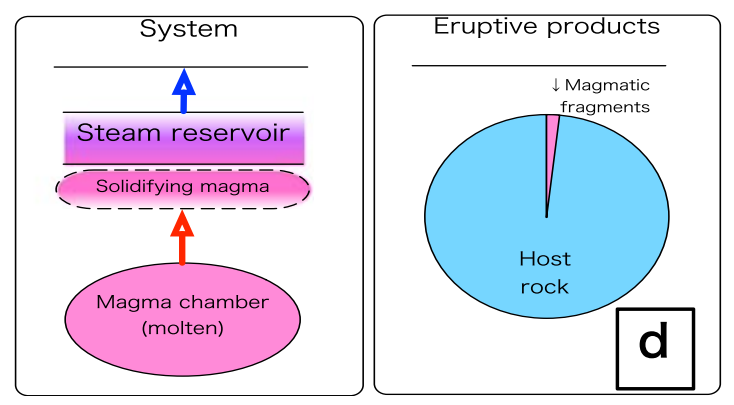

the movement of magma and the blue one host rock. Not to scale. We assume the depth of chambers to be 4-12 km, and the water/steam reservoirs to be $\sim 4 \mathrm{~km}$ 
gas sources are the magma and external water heated by the magma. However, for phreatic eruptions, the heat source is unclear. In this study, we investigated the lessaltered particles (LAPs) found in the 2014 eruption of Mount Ontake. We describe their petrological features and estimate their associated temperature, pressure, crystal content, and amount of excess magmatic $\mathrm{H}_{2} \mathrm{O}$ (i.e., vapor and supercritical aqueous fluid). We then test the hypothesis that the LAPs were derived from a shallow magma chamber that provided the heat and gas that generated this phreatic eruption (Fig. 1(d)).

\section{Geological setting}

Mount Ontake is an active basaltic to rhyolitic (dominantly andesitic) stratovolcano in the southern Norikura volcanic zone of central Japan (JMA, 2013) (Fig. 2; 35 53' 34.0" N, $\left.13^{\circ} 28^{\prime} 49.0^{\prime \prime} \mathrm{E}\right)$. Mount Ontake has been active in older (780 $390 \mathrm{ka})$ and more recent periods (100 ka to present) (Kioka et al., 1998; Matsumoto and Kobayashi, 1995, 1999; Yamada and Kobayashi, 1988), and is inferred to have had four magmatic eruptions and many phreatic eruptions in the past 10,000 years.

According to historical records, Mount Ontake did not erupt between the eighteenth century and 1979. Still, weak fumarolic activity in the Jigoku-dani area near the summit has been observed since the middle of the eighteenth century (Oikawa, 2008) after a long period of dormancy (> 5000 years?). Prior to the 2014 eruption, phreatic eruptions were recorded in 1979, 1991, and 2007, all in the Jigoku-dani area (Oikawa et al., 2014).

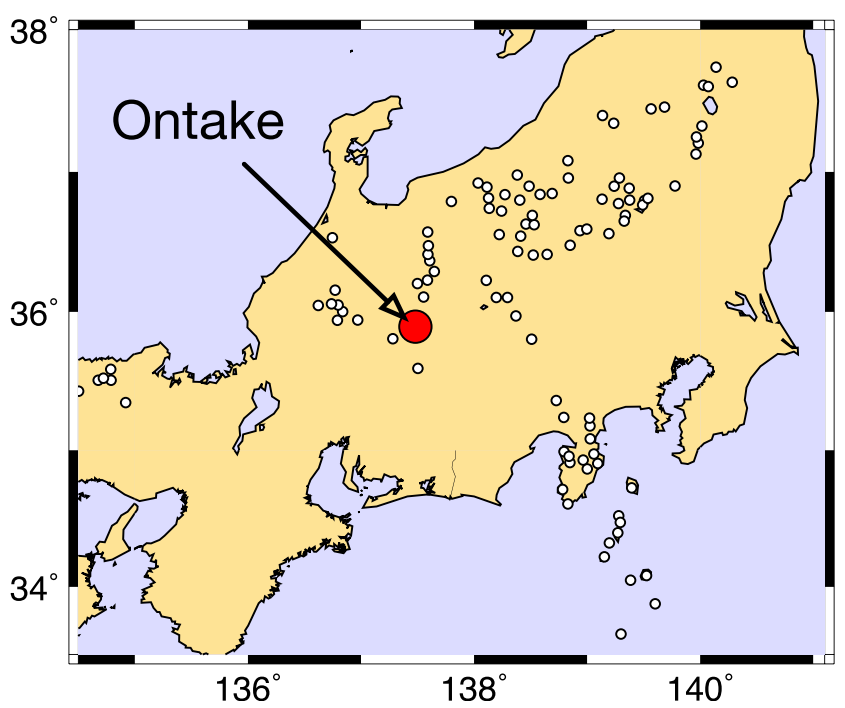

Fig. 2 Map showing the location of Mount Ontake (red circle) and Quaternary volcanoes (open circles) of Honshu Island, Japan

\section{The 1979 eruption}

The 1979 eruption occurred from vents aligned NW-SE at 2700-2900 m above sea level (asl) (Soya et al., 1980). The eruption was phreatic, and no juvenile material was identified within the eruption products, which comprised hydrothermally altered rock fragments containing smectite, halloysite $(7 \AA)$, and kaolinite (Ossaka et al., 1983; Soya et al., 1980). These clay minerals are characteristic of low temperatures close to Earth's surface, suggesting that weathering occurred during the long period of volcanic quiescence (Ossaka, 2003). Sulfur isotopic compositions of pyrite, anhydrite, and native sulfur from the volcanic ash record a reaction between volcanic $\mathrm{SO}_{2}$ gas and a wet mud reservoir below the crater zone (Kusakabe et al., 1982). Isotopic fractionation of oxygen between anhydrite and water indicates that the temperature of the mud reservoir prior to the eruption was $110-185^{\circ} \mathrm{C}$ (Kusakabe et al., 1982). Following the 1979 eruption, fumarolic activity spread to the Jigoku-dani and Haccho-tarumi areas, close to the summit of the volcano (Oikawa, 2008).

\section{The 1991 and 2007 eruptions}

Two small ash emissions occurred in 1991 and 2007 from several craters produced during the 1979 eruption (JMA, 1991; Nakamichi et al., 2009). It is possible that the precursors to phreatic eruptions are too weak to be detected by conventional volcano monitoring systems, which are generally designed for the detection of deep magmatic events (Barberi et al., 1992). However, ground deformation analysis techniques allowed a magmatic intrusion event to be detected at a depth of $3 \mathrm{~km}$ beneath Mount Ontake in 2007 (Nakamichi et al., 2009). Global navigation satellite system (GNSS) data indicate that the volume change during the 2007 intrusion was $6 \times 10^{6} \mathrm{~m}^{3}$, of which $5.5 \times 10^{6} \mathrm{~m}^{3}$ was associated with intrusion into an open fault, with $0.32 \times 10^{6} \mathrm{~m}^{3}$ being intruded at a shallower level (Takagi and Onizawa, 2016). A drop in groundwater pressure was also observed $\sim 10 \mathrm{~km}$ southeast of the summit of Mount Ontake prior to the 2007 eruption, consistent with a magmatic intrusion (Koizumi et al., 2016).

\section{The 2014 eruption}

The 2014 eruption began at 11:52 Japan Standard Time (JST) (Coordinated Universal Time (UTC) +9) on 27 September 2014 (JMA, 2014). The eruption involved several vents aligned NW-SE, close to the Jigoku-dani area at $\sim 2700 \mathrm{~m}$ asl, along the southwestern side of the lower section of Kengamine peak. Volcanic blocks were ejected during the eruption and were observed within $\sim 1 \mathrm{~km}$ of the craters (Oikawa et al., 2015). The eruption caused numerous fatalities related to the impact of ballistic ejecta, with calculated energy of $\sim 4.2 \times 10^{4} \mathrm{~J}$ (Tsunematsu et al., 2016). A pyroclastic density current flowed 
$\sim 3 \mathrm{~km}$ to the south from the vent (Kaneko et al., 2016; Maeno et al., 2016; Nakano et al., 2014; Oikawa et al., 2016; Yamamoto, 2014). A small $\left(\sim 1.2 \times 10^{5} \mathrm{~m}^{3}\right)$ lahar and a stream of hot water were expelled from Jigoku-dani crater and extended $\sim 5 \mathrm{~km}$ downstream (Sasaki et al., 2016). The eruption column reached a height of $7000 \mathrm{~m}$ above the craters and drifted towards the east (Sato et al., 2017; Takeshita et al., 2017). The total discharged mass during the 2014 eruption has been estimated as $0.89-1.20 \times 10^{6} \mathrm{t}$ (Takarada et al., 2016) or $0.63-$ $1.40 \times 10^{6} \mathrm{t}$ (Maeno et al., 2016).

The 2014 eruption followed a swarm of shallow volcanic-tectonic earthquakes and long-period events from August to September 2014 on a near-vertical plane oriented NNW-SSE, which migrated upward following the 2014 eruption. This observation indicates the presence of a vertical conduit beneath the summit area, which was filled with pressurized fluid prior to the 2014 eruption (Kato et al., 2015). GNSS data indicate that the ground inflated by $0.38 \times 10^{6} \mathrm{~m}^{3} 7 \mathrm{~min}$ prior to the eruption, although the volume change at depth was comparatively small (Takagi and Onizawa, 2016). Stacking of GNSS data revealed that a small volume change occurred immediately beneath the summit from 1 month prior to the eruption, as well as a small volume increase at depth from 1.5 months before the eruption (Miyaoka and Takagi, 2016). These volume increases were much smaller than those associated with the 2007 eruption (Miyaoka and Takagi, 2016). A very long period (VLP) seismic event occurred $25 \mathrm{~s}$ before the eruption, suggesting that preexisting volcanic-tectonic faults ruptured immediately prior to the eruption at depths of 300-1000 m (Maeda et al., 2015). The source locations of the volcanic tremor associated with the eruption descended by $\sim 2 \mathrm{~km}$ in the minutes prior to the eruption, likely reflecting the downward migration of volcanic fluids undergoing a phase transition beneath the crater (Ogiso et al., 2015).

Petrological observations revealed that volcanic ash particles consisted of altered volcanic fragments and minerals produced during acidic hydrothermal alteration; juvenile material was not observed (Ikehata and Maruoka, 2016; Minami et al., 2016). The observed minerals were estimated to have been sourced from a depth of 2-4 km to the near-surface (Minami et al., 2016). No significant differences in mineral assemblages or sulfur isotopic compositions were detected between the 2014 and 1979 ash, suggesting geochemical similarities in the underlying hydrothermal system during these events (Ikehata and Maruoka, 2016). However, UAV (an unmanned aerial vehicle)-based magmatic gas measurements indicated a high flux of $\mathrm{SO}_{2}(>2000 \mathrm{t} /$ day) until at least $20 \mathrm{~h}$ after the onset of the eruption, implying a significant input of magmatic gas, the majority of which was likely derived from high-temperature magmatic fluids at depth (Mori et al., 2016).

\section{Samples and analytical methods}

\section{Collection of volcanic ash}

We collected volcanic ash samples from the Kaida Plateau district, located $\sim 7-8 \mathrm{~km}$ downwind and to the east of the vent, at 08:00 JST on September 28, 2014, approximately $20 \mathrm{~h}$ after the eruption. Ash samples, NG140928-02 and NG140928-03, were collected at $35^{\circ} 55^{\prime} 09.8^{\prime \prime} \mathrm{N}-137^{\circ} 33^{\prime}$ $23.2 \mathrm{E}$ and $35^{\circ} 54^{\prime} 46.5^{\prime \prime} \mathrm{N}-137^{\circ} 32^{\prime} 42.8 \mathrm{E}$, respectively (Fig. 3). Sorting and dispersal of the ash deposit suggest emplacement as ashfall. The sampled ash was light gray in color and dry, although several aggregated clots were observed.

\section{Grain size and optical observations}

The ash samples have a size ranging from coarse to fine ash, with the largest particles having a diameter of $0.5 \mathrm{~mm}$. The sample NG140928-03 yielded a particle size distribution as follows: $<0.125 \mathrm{~mm}=81.4 \mathrm{wt} \%, 0.125-0.250 \mathrm{~mm}=$ $12.3 \mathrm{wt} \%, 0.250-0.500 \mathrm{~mm}=5.7 \mathrm{wt} \%$, and $>0.5 \mathrm{~mm}=$ $0.6 \mathrm{wt} \%$. The ash particles with diameters of $>0.25 \mathrm{~mm}$ are dominated by hydrothermally altered lithic fragments ranging in color from white (40-50\%) to gray (30-40\%) (Fig. 4(a)). These ash particles can be divided into two groups: whitepale gray porous grains and pale gray grains with glossy surfaces. The porous grains comprise a mixture of quartz, anhydrite, and pyrite crystals. In addition, less-altered lithic fragments with vitreous surfaces (Fig. 4(b)), oxidized lithic fragments, and isolated pyrite crystals and other crystal fragments were observed.

The fragments with vitreous surfaces, hereafter referred to as LAPs, may represent juvenile magmatic material, as the particles are angular and surrounded by fractured surfaces (Fig. 4(b)). In the sample NG140928-02, LAPs comprise $0.73 \mathrm{wt} \%$ of the analyzed ash particles with grain sizes of $>$ $0.25 \mathrm{~mm}$.

\section{Analytical methods}

X-ray diffraction (XRD) patterns were obtained from a bulk unprocessed ash sample (NG140928-02). XRD measurements were conducted using a Rigaku-RINT2000 instrument at a voltage of $40 \mathrm{kV}$, current of $100 \mathrm{~mA}$, and steps of $0.02^{\circ}$ at a rate of $5 \% \mathrm{~min}$. These measurements were made on glass slides with a thickness of $0.4 \mathrm{~mm}$.

For optical and scanning electron microscopy (SEM) observations, the ash samples were dried at $90{ }^{\circ} \mathrm{C}$ for several hours, weighed, washed with deionized water and ultrasonicated for $\sim 1 \mathrm{~h}$, dried, weighed, and then sieved through mesh diameters of 500, 250, and $125 \mu \mathrm{m}$. Surface textures of some LAPs were observed using a SEM (JEOL JSM-6610LV) at the Geological Survey of Japan (GSJ), 
Fig. 3 Volcanic ashfall from Mount Ontake on the morning of 28 September 2014. (a) Ash deposited on a tennis court in the Kaida highland area $\left(35^{\circ} 55^{\prime}\right.$ $09.8^{\prime \prime} \mathrm{N}, 137^{\circ} 33^{\prime} 23.2^{\prime \prime}$ E, 08:46 JST), $\sim 8.0 \mathrm{~km}$ from the vent at $1450 \mathrm{~m}$ asl. The unit of the scale bar is $10 \mathrm{~cm}$. (b) Ash deposited on leaves at a GNSS observatory $\left(35^{\circ} 54^{\prime} 46.0^{\prime \prime} \mathrm{N}, 137^{\circ} 32^{\prime} 42.8^{\prime \prime}\right.$ E, 09:16 JST), $\sim 6.8 \mathrm{~km}$ from the vent at $1500 \mathrm{~m}$ asl. The unit of the scale bar is in cm. (c) Sampling locations of the ash samples. Redrimmed yellow circles indicate the locations of the photographs in "a" and "b." The isopleth mass $\left(\mathrm{g} / \mathrm{m}^{2}\right)$ distribution of the 27 September 2014 eruption of Ontake volcano is after Takarada et al. (2016). The base map is from opentopomap.org
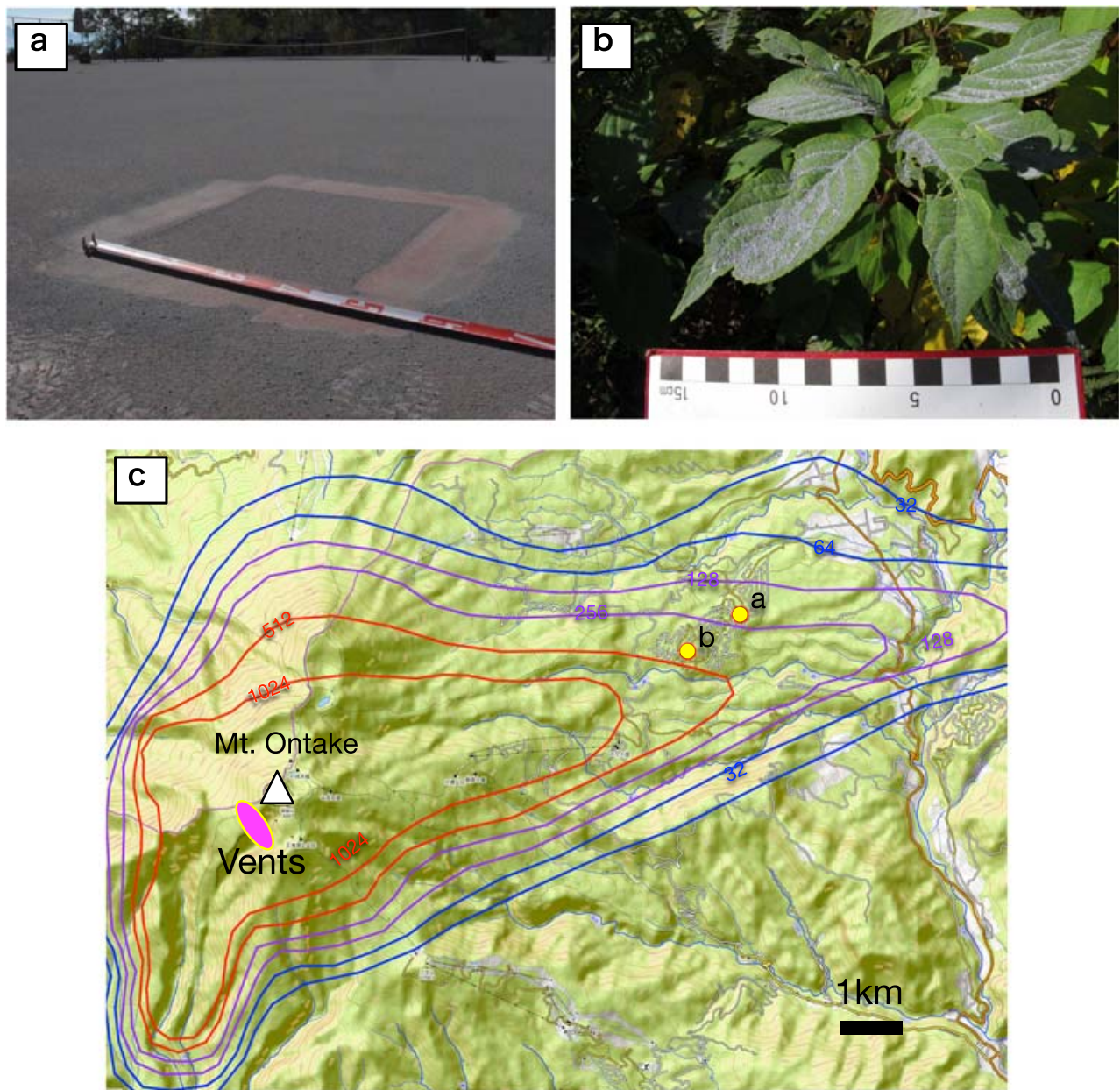

Tsukuba, Japan, with an accelerating voltage of $15 \mathrm{kV}$, a probe current of $1.0 \mathrm{nA}$, and a focused electron beam. Ash particles with diameters of $>250 \mu \mathrm{m}$ were attached to conductive double-sided adhesive tape (Nisshin EM Co. Ltd., Tokyo) to allow observation of their surface microstructures. The chemical compositions of glasses and minerals were analyzed with an electron probe microanalyzer (EPMA). The ash particles were mounted on a glass disk (thickness $=5 \mathrm{~mm}$; diameter $=$ $24 \mathrm{~mm}$ ), embedded in resin, and polished, where the particles were ordered in a single, closely packed layer to achieve maximum exposure.

Prior to chemical analysis, back-scattered electron images (BEI) were obtained using a JEOL JXA-8900 EPMA at GSJ, with an accelerating voltage of $15 \mathrm{kV}$, a probe current of $12 \mathrm{nA}$, and a probe diameter of $1 \mu \mathrm{m}$. The BEI $(1000 \times$ 1000 pixels with a pixel size of $1 \times 1 \mu \mathrm{m}$ ) were then stitched together to create mosaics of entire polished sections. Each BEI was collected using at least two different brightness/
Fig. 4 Photomicrographs of ash particles (NG140928-02) after washing, sieving (>0.25 mm), and subdivision into altered and less-altered particles under a binocular microscope. (a) White to gray, altered, lithic fragments (NG140928-02-a). The scale bar is $1.0 \mathrm{~mm}$. (b) Rare (<0.7 wt.\%) less-altered particles (NG140928$02-\mathrm{k}$ ). Scale bar is $0.5 \mathrm{~mm}$
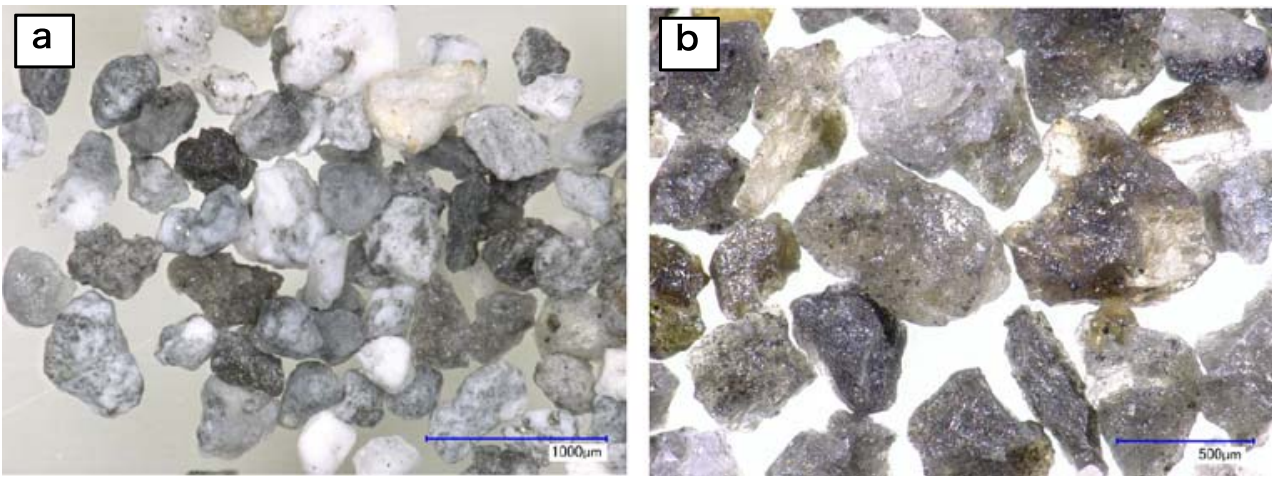
contrast configurations: one to image plagioclase and melt inclusions, and the other for mafic minerals, such as hornblende, pyroxene, and olivine (see Online Resource 1).

Major element concentrations ( $\mathrm{Si}, \mathrm{Ti}, \mathrm{Al}, \mathrm{Fe}, \mathrm{Mn}, \mathrm{Mg}, \mathrm{Ca}$, $\mathrm{Na}, \mathrm{K}, \mathrm{S}, \mathrm{Cl}$, and $\mathrm{F}$ ) of phenocrysts and phenocryst-hosted melt inclusions were measured using a JEOL JXA-8900 EPMA at the GSJ, with an accelerating voltage of $15 \mathrm{kV}$, a probe current of $12 \mathrm{nA}$, and a probe diameter of $4 \mu \mathrm{m}$. The instrument was equipped with a wavelength-dispersive X-ray spectrometer (WDS), and standard ZAF (the atomic-number effect, the absorption effect, and the fluorescence excitation effect) corrections were applied to the acquired data. Positions of the EPMA analyses are shown in Online Resource 2. Sodium loss during electron bombardment was prevented by using a defocused electron beam (Hamada and Fujii, 2007, $10 \mu \mathrm{m}$ for smaller melt inclusions), as well as by analyzing $\mathrm{Na}$ first with a 4-s counting time. Sulfur, $\mathrm{Cl}$, and $\mathrm{F}$ were measured using a 50-s counting time.

We used the Rhyolite-MELTS 1.2.0 software package (Gualda et al., 2012), which is an optimized version of the MELTS program (Asimow and Ghiorso, 1998; Sack et al., 1980), to calculate the proportions and compositions of minerals and hydrous melt in equilibrium at varying pressure, temperature, and oxygen fugacity, as well as $\mathrm{H}_{2} \mathrm{O}$ and $\mathrm{CO}_{2}$ concentrations, for batch and fractional crystallization. Calculations were performed at pressures of $0.1-850 \mathrm{MPa}$ in $10 \mathrm{MPa}$ steps; temperatures of $700-1400{ }^{\circ} \mathrm{C}$ in $1{ }^{\circ} \mathrm{C}$ steps; oxygen fugacities of FMQ (fayalite-magnetite-quartz) to FMQ + 3; $\mathrm{CO}_{2}$ concentrations of $0.001,0.010,0.100$, and 0.999 wt $\%$; and $\mathrm{H}_{2} \mathrm{O}$ concentrations of $0.1-1.0 \mathrm{wt} \%$ at intervals of $0.1 \mathrm{wt} \%, 1.0$ $6.0 \mathrm{wt} \%$ at intervals of $0.5 \mathrm{wt} \%$, and $8.0 \mathrm{wt} \%$. The total number of possible combinations of these parameters is approximately 44 million per sample. For each $\mathrm{P}-\mathrm{T}-\mathrm{H}_{2} \mathrm{O}-\mathrm{CO}_{2}-\mathrm{fO}_{2}$ combination, we obtained various MELTS outputs, including the amounts and compositions of phases, in addition to physical parameters such as melt viscosity. These are summarized in a suite of P-T contour maps (Online Resource 3 ) using our own
Perl (Wall and Schwartz, 1991) scripts and generic mapping tools (Wessel and Smith, 1998).

\section{Results}

\section{Hydrothermally altered minerals}

X-ray diffraction patterns of bulk ash powders (sample NG140928-02) indicate the presence of quartz, cristobalite, tridymite, pyrite, and anhydrite, with minor alunite, gypsum, kaolinite, and illite (Fig. 5). Smectite was rarely detected. Although some quartz and cristobalite may have been derived from minerals in the Ontake volcanic rocks, we infer that they were mainly produced during hydrothermal alteration, as many ash grains show clear evidence for this (Minami et al., 2016).

\section{Surface textures of less-altered ash particles}

SEM observations showed that the surfaces of some LAPs have etch pits a few tens of microns in diameter that formed through leaching of groundmass minerals in the original volcanic rocks (Fig. 6(a)). In addition, druse minerals and aligned clusters of fine pyrite grains (a few microns in diameter) were observed on some surfaces (Fig. 6(a)). We did not find any hydration cracks nor quench cracks on the surface of LAPs.

\section{Classification of LAPs}

LAPs were examined in BEI (Online Resource 1, 2, 4) and optical images (Online Resource 5). We used the microtextures of the ash particles observed in the BEI to classify the LAPs into five groups, which are referred to as Gls (glassy particles), Xtn (holocrystalline particles), Fx (free crystals), Alt (altered particles), and Unc (unclassified particles) (Online Resource 6, 7).
Fig. 5 X-ray diffraction pattern of a bulk ash powder (sample NG140928-02). Diffraction peaks were identified as quartz $(\mathrm{Q})$, pyrite (Py), anhydrite (Ah), cristobalite (Cr), tridymite ( $\mathrm{Tr}$ ), gypsum $(\mathrm{Gp})$, kaolinite $(\mathrm{Ka})$, illite (Il), and plagioclase (Pl)

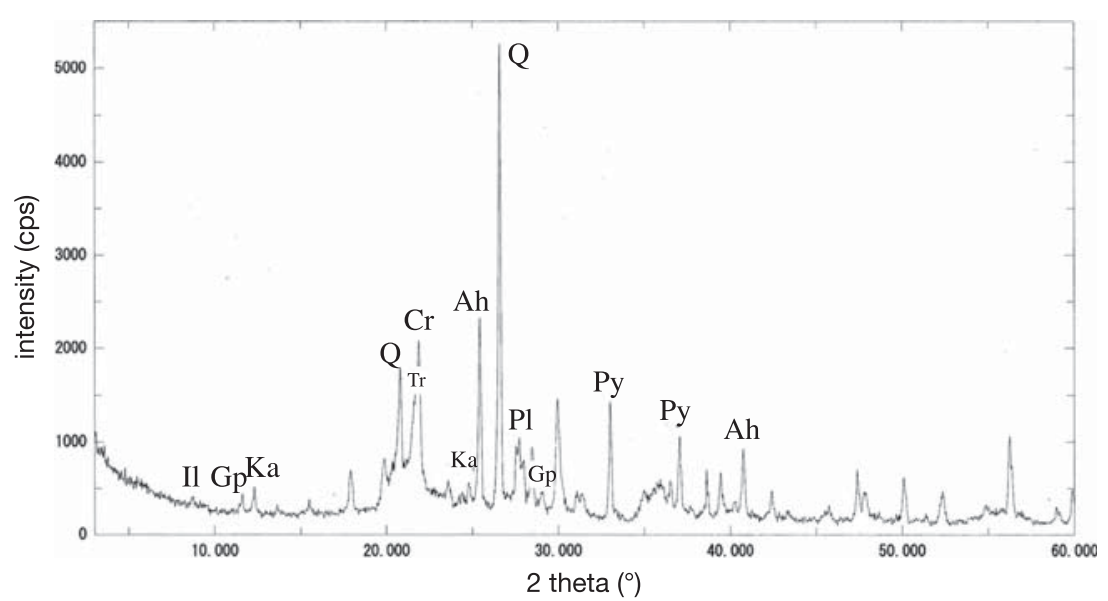




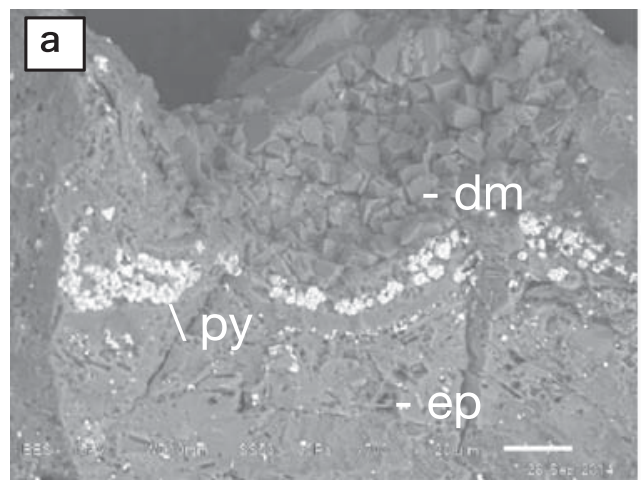

Fig. 6 SEM images of less-altered particles. (a) Surface textures of lessaltered particles (sample NG140928-02). The surface contains etch pits (ep), pyrite (py), and druse minerals (dm). Scale bar $=20 \mu \mathrm{m}$. (b) Backscattered electron images of polished thin sections of less-altered particles

The Gl group comprises unaltered magmatic particles in a matrix of glass and microlites, and sometimes contain microphenocrysts (Fig. 7(a)). These glassy particles contain rhyolitic glass, plagioclase, orthopyroxene, clinopyroxene, hornblende, magnetite, ilmenite, silica minerals, and vesicles (Fig. 6(b)). Vesicles in Gls are less than a few tens of microns in diameter, elongate, and do not contain mineral precipitates (Fig. 6(b)). BEIs indicate that the chemical compositions of Gls are variable, suggesting differences in magmatic temperatures. Approximately $50 \%$ of Gls contain relatively large (> $100 \mu \mathrm{m})$ plagioclase microphenocrysts that have dark cores and lighter rims (i.e., reversely zoned). The other plagioclase microphenocrysts are relatively bright, normally zoned plagioclase microlites (Fig. 7(a)). These textures suggest that the magma was relatively low in temperature and was then heated prior to eruption. Approximately $25 \%$ of Gls contain relatively bright cores (sometimes with dusty textures; Online Resource 6-133_Gls.png) and contain normally zoned plagioclase microphenocrysts. More than half of the Gls contain dark, flat plagioclase microlites. This texture suggests that the magma was relatively high in temperature, and had crystallized and cooled before the eruption. Some of the reversely zoned plagioclase microphenocrysts also occur as fragments with very thin or no crystal growth preserved along fracture surfaces (Online Resource 6-094_Gls.png), suggesting that heating took place before the fragmentation and was followed shortly after by the eruption. Silica minerals in Gls are either euhedral or rounded (Fig. 6(b)). Hornblende phenocrysts are euhedral to anhedral in shape. Pyroxene grains are either normally or reversely zoned and may contain melt inclusions.

The Xtn group comprises unaltered holocrystalline magmatic particles containing a micrographic matrix of orthoclase and quartz (Fig. 7(b)), which occasionally contain phenocrysts. The larger plagioclase crystals in Xtn are normally zoned (Fig. 7(b)). Melt inclusions were rarely observed in phenocrysts in Xtn. The Xtn particles contain plagioclase, $\mathrm{K}$-feldspar, silica minerals, hornblende, magnetite, and rutile.

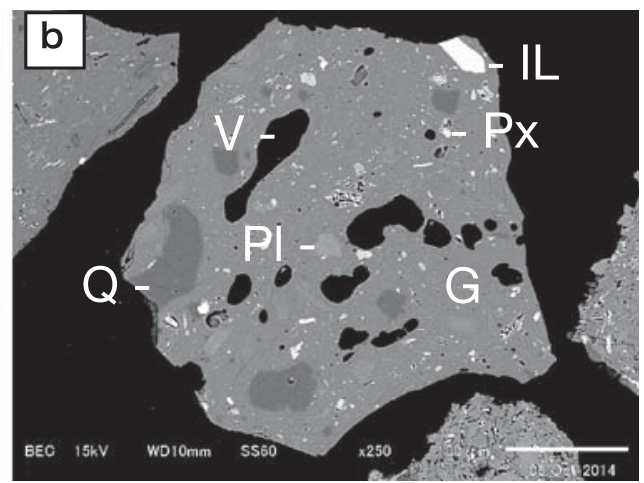

(sample NG140928-02-k). Glassy particles contain unaltered rhyolitic glass $(\mathrm{G})$, eroded quartz $(\mathrm{Q})$, spherical to elongate vesicles $(\mathrm{V})$, orthopyroxene $(\mathrm{Px})$, plagioclase $(\mathrm{Pl})$, and ilmenite (IL). Scale bar $=$ $100 \mu \mathrm{m}$

Plagioclase, K-feldspar, and silica minerals form a micrographic texture (Fig. 7(b)), which is characterized by regular intergrowths of two minerals (commonly quartz and alkali feldspar) (MacKenzie et al., 1982). This texture contrasts with the colloform textures observed in the altered grains, which comprise K-feldspar-rich bands and a fine-grained mixture of silica minerals and K-feldspar (Minami et al., 2016). Granophyric textures characterized by a radiating groundmass of feldspar grains around feldspar phenocrysts were not identified in Xtn. Rare devitrified melt inclusions were observed in some Xtn. Textures of plagioclase microphenocrysts (> $100 \mu \mathrm{m})$ in Xtn are similar to those observed in Gls; some have bright cores (sometimes dusty; Online Resource 6117_Xtn.png) and are normally zoned. Some plagioclase microphenocrysts have dark cores and are reversely zoned (with or without dusty zones; Online Resource 6130_Xtn.png and Online Resource 6-011_Xtn.png). All the plagioclase microphenocrysts, including reversely zoned crystals, have dark outermost rims. This texture suggests that Xtn had a similar thermal history, but a much lower final temperature than the Gls. Plagioclase phenocrysts also occur as fragments that have thin, normally zoned rims on fracture surfaces (Online Resource 6-095_Xtn.png and 116_Xtn.png), suggesting that there was a time for plagioclase to continue crystallization after the fragmentation at magmatic temperature before the eruption. Hornblende phenocrysts are euhedral to anhedral, and sometimes partially resorbed. Pyroxene phenocrysts were not observed in Xtn.

Free crystals (Fx) comprise unaltered phenocrysts, such as plagioclase and pyroxene (see "Fx: free crystals" in Online Resource 06). Instead, Alt consists of fragments of volcanic rocks with alteration features, such as glasses with lower $\mathrm{BE}$ intensities due to dissolution and hydration, loosely assembled microlites, and chalcedony deposition along the inner walls of voids (see "Alt: altered particles" in Online Resource 06). However, these altered particles appeared glossy and less altered under a binocular microscope 

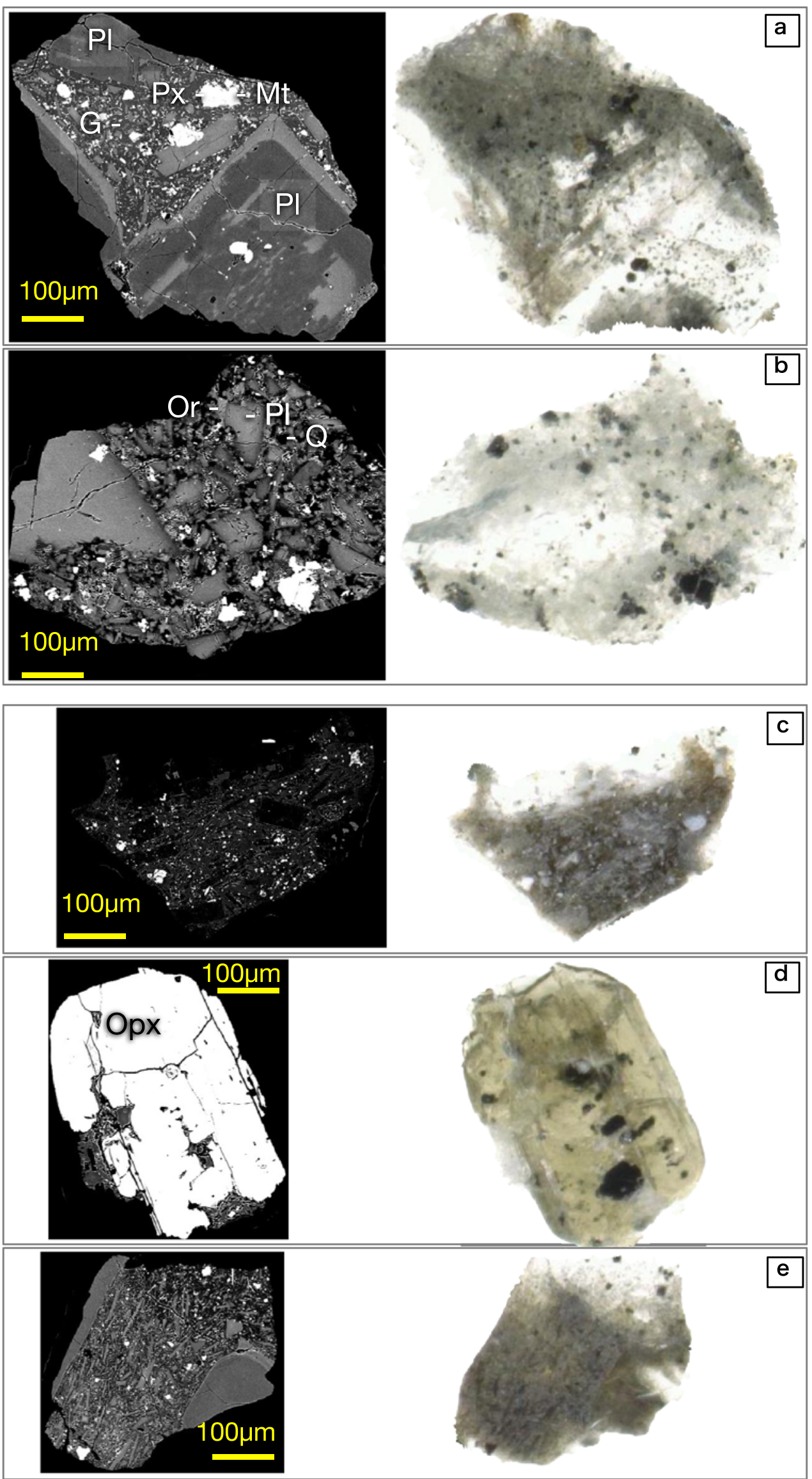
Fig. 7 Back-scattered electron images (brightness and contrast optimized for plagioclase) (left) and corresponding optical microscopy images (right) of polished thin sections of rare less-altered particles (sample NG140928-02-k). (a) Glassy particle (Gls) containing unaltered rhyolitic glass $(\mathrm{G})$, clinopyroxene (Px), plagioclase $(\mathrm{Pl})$, and magnetite $(\mathrm{Mt})$. (b) Holocrystalline particle (Xtn) containing plagioclase phenocrysts $(\mathrm{Pl})$ set in a micrographic matrix comprising orthoclase (Or) and quartz (Q). (c) Grains interpreted as altered volcanic rocks (Alt) due to the dissolution and/or precipitation of altered minerals observed in SEM images, although these appeared glossy and less altered under a binocular microscope. (d) Unaltered free crystals (Fx). (e) Unclassified particles (Unc)

(Fig. 7(c)). The Unc group are unclassified magmatic particles because of multiple features, e.g., partly altered (see "Unc: unclassified particles" in Online Resource 06). The abundances of these five types of LAPs $(n=135$;
Online Resource 6) are as follows: Alt $=27$ particles $(20 \%)$, Gls $=64$ particles $(47 \%), \mathrm{Xtn}=12$ particles $(9 \%), \mathrm{Fx}=17$ particles $(13 \%)$, and $\mathrm{Unc}=15$ particles $(11 \%)$.

\section{Relationship between textures and compositions}

Whole-rock compositions of the LAPs could not be measured due to their small size. Previously reported whole-rock data from Ontake volcano (Yamada and Kobayashi, 1988) fall within the medium- and high-K fields (Gill, 1981) on a $\mathrm{SiO}_{2}$ vs. $\mathrm{K}_{2} \mathrm{O}$ diagram (Fig. 8(h)). The compositions of melt inclusions and matrix glass from LAPs cluster along with the same compositional trend for the whole-rock samples (Fig. 8(h)). Melt inclusions and matrix glass both have high-silica
Fig. 8 Variations in silica contents of glass and minerals within less-altered particles (sample NG140928-03-k) and wholerock samples of the 2014 Ontake eruption. (a) $\mathrm{TiO}_{2}$, (b) $\mathrm{Al}_{2} \mathrm{O}_{3}$, (c) $\mathrm{FeO}$, (d) $\mathrm{MnO}$, (e) $\mathrm{MgO}$, (f) $\mathrm{CaO}$, (g) $\mathrm{Na}_{2} \mathrm{O}$, and (h) $\mathrm{K}_{2} \mathrm{O}$. WRy, whole-rock samples of younger Ontake eruptive products; WRo, whole-rock samples of older Ontake eruptive products; Plg, plagioclase; Kfs, K-feldspar; MG, matrix glass; MIs, melt inclusions; Px, pyroxene; Hb, hornblende; TD, whole-rock compositions used for thermodynamic calculations with RhyoliteMELTS (Gualda et al., 2012). There are two compositions for TD. One is $51.7 \mathrm{wt} \% \mathrm{SiO}_{2}$ (older Ontake deposit; $750 \mathrm{ka}$; OT30) and another with $60.4 \mathrm{wt} \% \mathrm{SiO}_{2}$ (OT16; youngest lava flow) (data from Yamada and Kobayashi, 1988)
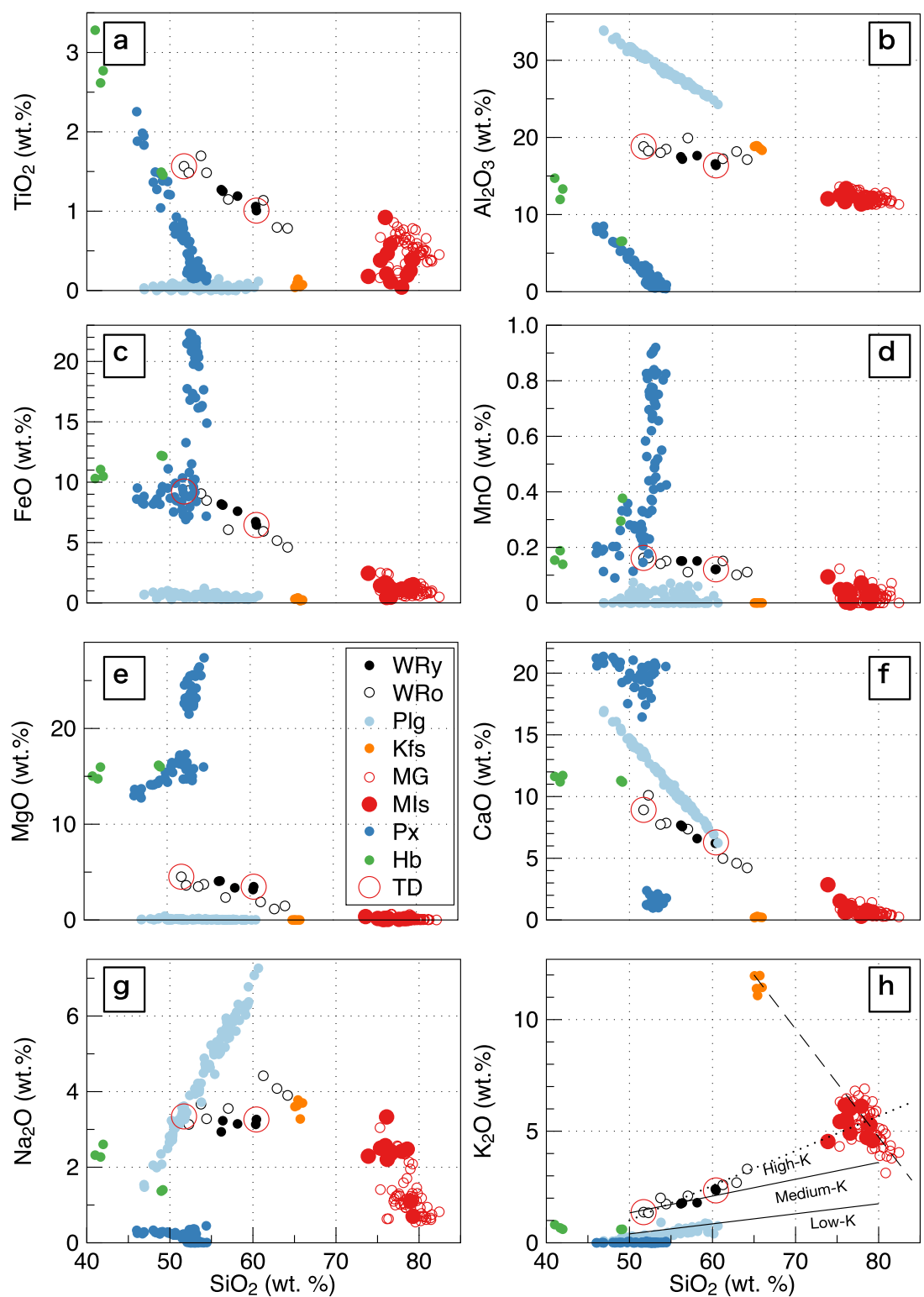
rhyolitic compositions $\left(\mathrm{SiO}_{2}=75-80 \mathrm{wt} \%\right)$. However, the matrix glass has higher $\mathrm{SiO}_{2}$ (Fig. 9(a)) and $\mathrm{TiO}_{2}$ (Fig. 9(b)), and lower $\mathrm{Na}_{2} \mathrm{O}$ (Fig. 9(c)) contents than the melt inclusions. This variation in glass composition correlates with brightness in BEI. Note, for example, that lighter tones are associated with relatively low-silica glass (cf. Online Resource 6063_Gls.png) and darker tones with relatively high-silica ones (cf. Online Resource 6-035_Gls.png). Compositions of plagioclase grains in Gls and Xtn range from 38 to 86 and 31 to $81 \mathrm{~mol} \%$ anorthite (An), respectively, with two modes at $\mathrm{An}=47$ and $70 \mathrm{~mol} \%$ (Fig. 10). The composition of orthopyroxene in Gls ranges from 63 to $75 \mathrm{~mol} \%$ enstatite (En) (Fig. 11(a), (b)) with modes at 64 and $70 \mathrm{~mol} \%$, whereas those in other analyzed particles ( $\mathrm{Fx}$, Alt, and Unc) range from 61 to 67 mol\% En, with a mode at 64 mol\% En. Orthopyroxene and clinopyroxene contain $2-5$ and $31-$ 36 mol\% wollastonite (Wo), with modes at 2.5 and $42 \mathrm{~mol} \%$, respectively (Fig. 11(c)). The composition of individual magnetite grains and those within Gls cluster around 2$3 \mathrm{wt} \% \mathrm{Al}_{2} \mathrm{O}_{3}$ (stoichiometrically corrected), with $\mathrm{Mg} / \mathrm{Mn}$ molar ratios of $0.1-10$, whereas those in Xtn contain 1.0 wt. $\% \mathrm{Al}_{2} \mathrm{O}_{3}$ and $\mathrm{Mg} / \mathrm{Mn}$ molar ratios of $0.1-1$ (Fig. 12(a)). These mineral compositions indicate that Gls formed over a wide range of temperatures, whereas Xtn record low temperatures, close to the minimum value of the Gls. Although the textures of Gls and Xtn are different, their chemical compositions overlap.

Both Gls and Xtn contain two types of hornblende phenocryst. The first contains 1.9-2.4 Al atoms per formula unit (pfu; normalized to 15 cations) and 39.8-42.8 wt\% $\mathrm{SiO}_{2}$ (Hb in Fig. 8). These compositions are comparable with those reported by Takeshita (2004) from Mount Ontake tephra that was erupted during its earlier period of activity. The second type of hornblende phenocryst contains $1.1 \mathrm{Al}$ pfu and 49.2$49.4 \mathrm{wt} \% \mathrm{SiO}_{2}$, which is similar to hornblende compositions that crystallize in shallow magma chambers (e.g., $1.1 \mathrm{Al}$ pfu and $51 \mathrm{SiO}_{2} \mathrm{wt} \%$; estimated depth of formation $=3.3 \pm$ $2.4 \mathrm{~km}$; Miyagi et al., 2017).

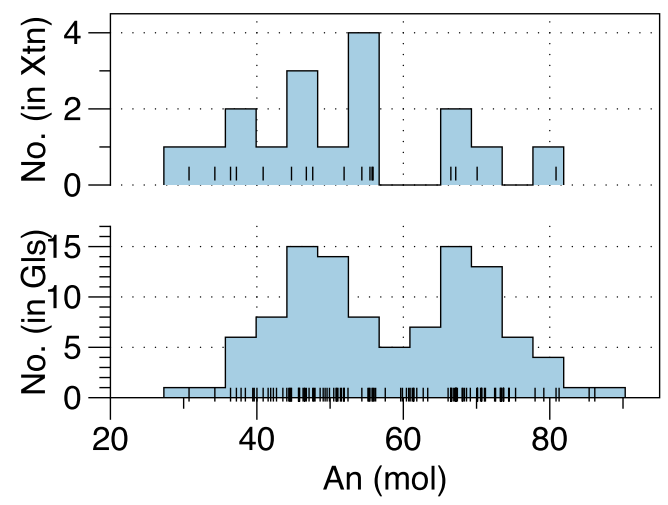

Fig. 10 Histogram of the anorthite contents (mol\%), with individual measurements (black ticks) in plagioclase grains in LAPs (sample NG140928-03-k). The upper shows for Gls (glassy particle, containing unaltered rhyolitic glass) and the lower one for Xtn (holocrystalline particle)

\section{Discussion}

\section{Type of eruptions}

Primary volcanic processes of pyroclastic eruptions are recognized (Cas and Wright, 1987) as follows: (1) magmatic eruptions, (2) phreatomagmatic eruptions, and (3) phreatic eruptions (Fig. 1). If even small amounts of juvenile magma fragments are found, the eruption would be classified as phreatomagmatic (Browne and Lawless, 2001). However, in several cases, it appears that phreatic-like deposits can contain small portions of juvenile material (Alvarado et al., 2016; Cashman and Hoblitt, 2004; Gaunt et al., 2016). For example, Cashman and Hoblitt (2004) and Alvarado et al. (2016) reported that volcanic ash from the 28 March 1980 eruption at Mt. St. Helens (USA), and from the 2010-2016 eruption of Turrialba volcano (Costa Rica), which were previously considered phreatic eruptions, actually contained magmatic particles, so are now cataloged as phreatomagmatic eruptions. Here we, therefore, emphasize the fact that many deposits that have the appearance of a phreatic eruption under the naked eye, and even under the binocular

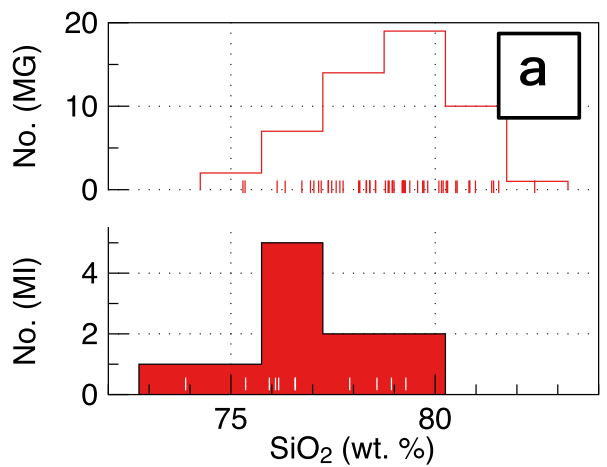

Fig. 9 Histograms of melt compositions, with locations of individual measurements (red and white ticks). MG, matrix glass in LAPs; MI,
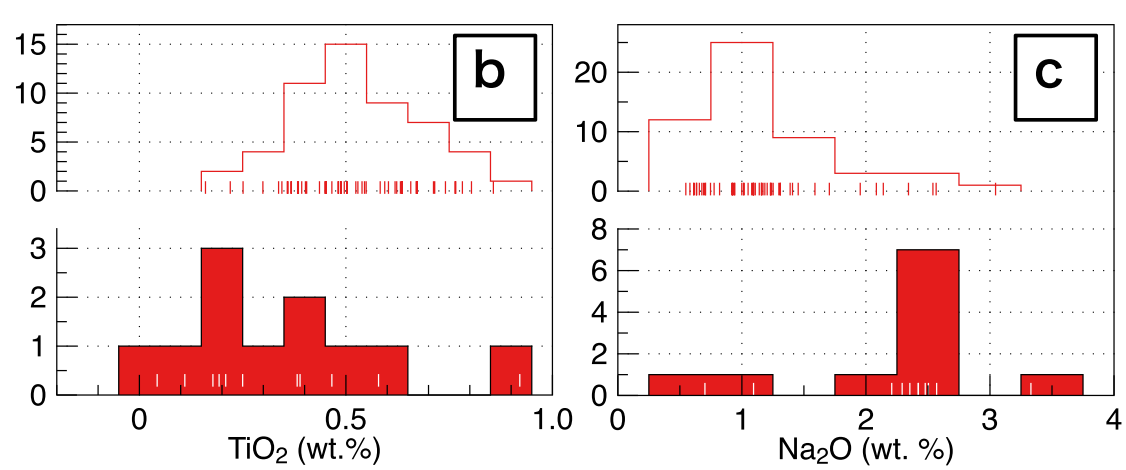

melt inclusions in LAPs. (a) $\mathrm{SiO}_{2}$ wt $\%$. (b) $\mathrm{TiO}_{2}$ wt $\%$. (c) $\mathrm{Na}_{2} \mathrm{O}$ wt $\%$. (sample NG140928-03-k) 
Fig. 11 Chemical composition of pyroxenes in LAPs (sample NG140928-03-k)

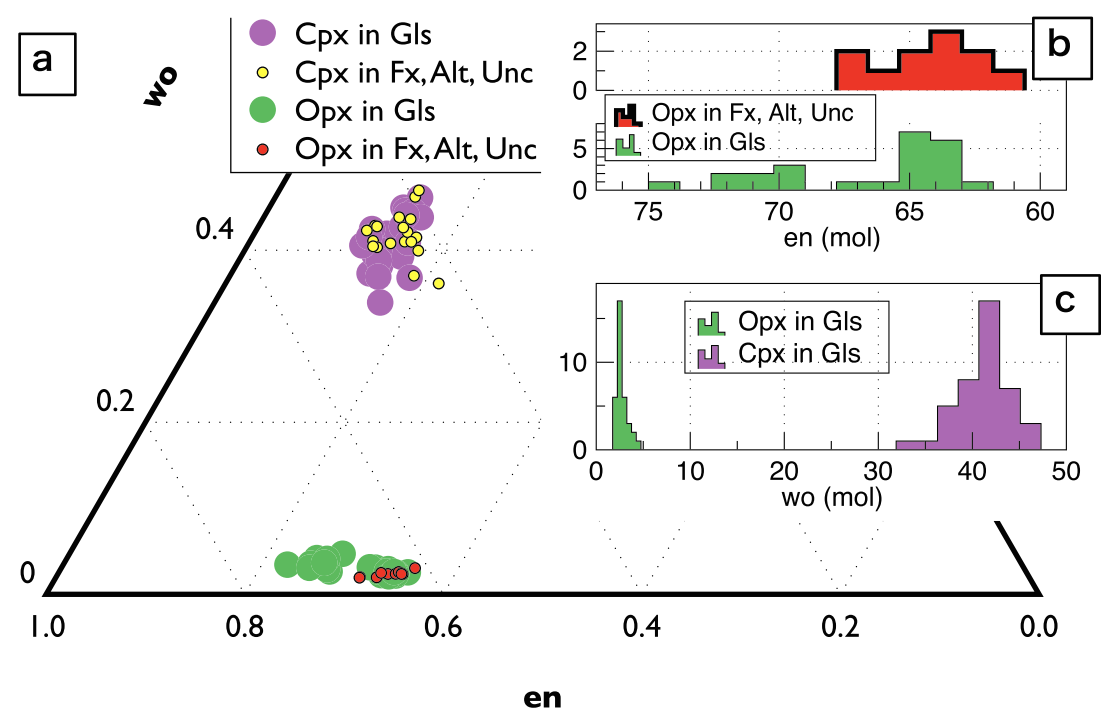

microscope, have a possibility of containing a very low percentage of glass that appear to be juvenile. We also note that, in the determination of magmatic and phreatomagmatic eruptions raised by White and Valentine (2016), they argue that "the absence of evidence for phreatomagmatic fragmentation is not evidence of absence."

In the case of the 2014 eruption of Ontake volcano, as shown above, the ash contains trace amounts of LAPs, considered magmatic particles. However, it is not our intention to reclassify previously identified phreatic eruptions as phreatomagmatic. Because the majority of the erupted material is hydrothermally altered host rocks, the energy of the eruption was derived mainly from the heat of the underground steam reservoir. In the following, we propose a model in which the LAPs were derived from magma intruded into a hydrothermally altered zone and provided heat and gas to the hydrothermal system since the 2007 event by showing similarity of the depth of magma intrusion and the depth of the hydrothermal system. We also discuss the source of heat and magmatic gas in the 2014 eruption, as well as the reason why magma intruded in 2007, caused an eruption in 2014 after 7 years.

\section{The hydrothermal system of Mount Ontake}

\section{Alteration facies}

Hydrothermally altered rock fragments are the dominant component in the erupted material. The presence of alunite and kaolinite and lack of smectite in the tephra indicate that alteration occurred in an acidic environment. Hydrothermal quartz and illite likely formed at $>100{ }^{\circ} \mathrm{C}$ and $>200{ }^{\circ} \mathrm{C}$, respectively (Henley and Ellis, 1983a; Izawa, 1990; Reyers, 1990). Therefore, we infer that the tephra generated during the 2014 eruption was produced in an acidic hydrothermal system at $>200{ }^{\circ} \mathrm{C}$. Hydrothermally altered minerals were also
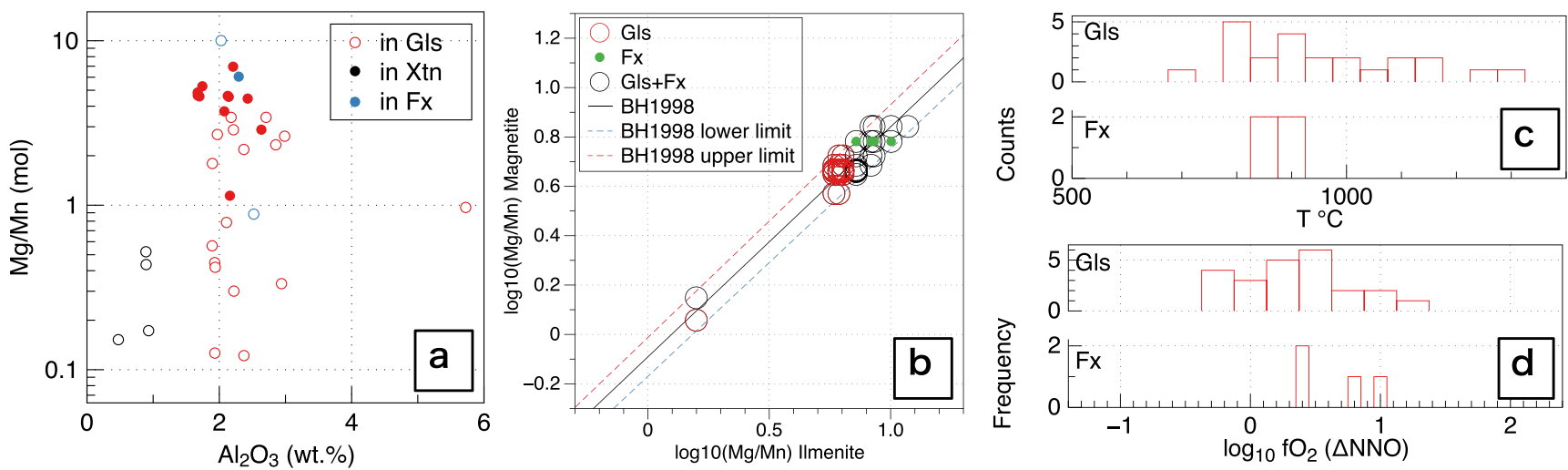

Fig. 12 Fe-Ti oxide geothermometry. (a) Selection of magnetiteilmenite pairs from LAPs (sample NG140928-03-k) using Mg/Mn partitioning, known as the Bacon and Hirschmann (1988) test. (b) Oxygen fugacities estimated using the FeTiOxideGeotherm application
(Ghiorso and Evans, 2008) with the magnetite-ilmenite pairs that passed the test in (a). (c) Histogram of the estimated temperature. (d) Histogram of the estimated oxygen fugacity 
dominant in the tephra of the 1979 eruption. However, smectite was observed in the 1979 tephra (Ossaka et al., 1983; Soya et al., 1980), indicating that the ejected material was derived from a hydrothermal system with a neutral $\mathrm{pH}$.

Acidic hydrothermal alteration commonly occurs along with fractures, which allows magmatic gas to ascend from depth (cf. Hamasaki, 2010; Hedenquist et al., 1994; Henley and Ellis, 1983b). Quartz, alunite, and kaolinite typically form the core of the hydrothermal alteration zones. Dilution of the acidic hydrothermal fluid through mixing with groundwater raises the fluid $\mathrm{pH}$, resulting in the formation of peripheral $\mathrm{pH}$ neutral alteration zones containing minerals such as smectite (cf. Hamasaki, 2010; Hedenquist et al., 1994; Henley and Ellis, 1983b). Therefore, the reduction in $\mathrm{pH}$ observed between the 1979 and 2014 eruptions might indicate the activation of a magmatic-hydrothermal system beneath the volcano. This conclusion is consistent with observations of geothermal activity at the surface following the 1979 eruption (Oikawa, 2008). Therefore, the development of acidic hydrothermal alteration zones was associated with the injection of magmatic gas into the hydrothermal system. $\mathrm{SO}_{2}$ emissions were detected following 1979 (Ossaka et al., 1983) and 2014 (Mori et al., 2016) eruptions. Acidic magmatic gas can be produced during the intrusion of a magma body at depth, consistent with the observed increase in seismic activity in 2006-2007 (Nakamichi et al., 2009).

The lack of juvenile material in the 1979 tephra suggests that the magmatic gas exsolved from the magma body and was injected into the hydrothermal system (Ossaka et al., 1983; Sugiura et al., 1983). However, the presence of glassy fragments in the 2014 tephra might indicate the presence of magmatic gas and a small amount of magma, which were injected into the hydrothermal system during the eruption.

\section{Temperature}

Magmatic temperatures of the LAPs were estimated using the FeTiOxideGeotherm 1.1.0 application of Ghiorso and Evans (2008), with compositions of selected magnetite-ilmenite pairs that passed the Bacon and Hirschmann (1988) test. Twelve out of 46 magnetite grains passed this test (Fig. 12(b), also shown in Fig. 12(a) as solid circles). No magnetite-ilmenite pairs from Xtn passed the Bacon and Hirschmann (1988) test. We tentatively infer that Xtn formed at $\sim 700{ }^{\circ} \mathrm{C}$, based on the following lines of evidence. First, Gls yielded temperatures of $700-1300{ }^{\circ} \mathrm{C}$ (Fig. 12(c)) and oxygen fugacities of -0.25 to $+1.25 \log _{10} \mathrm{fO}_{2} \Delta \mathrm{NNO}$ (Fig. 12(d)). However, a narrower range of temperatures from 700 to $950{ }^{\circ} \mathrm{C}$ is obtained by comparison of the observed melt compositions ( $>3.5 \mathrm{wt} \% \mathrm{~K}_{2} \mathrm{O}$ ) and the results of the thermodynamic computations (Fig. 13(e)). Second, $\mathrm{Mg} / \mathrm{Mn}$ ratios in Xtn correspond with those in Gls (Fig. 12(a)). Third, in general, lower $\mathrm{Mg} / \mathrm{Mn}$ ratios indicate lower temperatures.
The relatively rapid rate of chemical diffusion in $\mathrm{Fe}-\mathrm{Ti}$ oxides (Nakamura, 1995; Venezky and Rutherford, 1999) and the small amount of ground deformation prior to the 2014 eruption (Kato et al., 2015; Miyaoka and Takagi, 2016; Takagi and Onizawa, 2016) indicate that the observed wide range of temperatures $\left(700-1300{ }^{\circ} \mathrm{C}\right.$, but likely $\left.700-950{ }^{\circ} \mathrm{C}\right)$ reflect derivation of material from a thermally heterogeneous, near-solid, to partially molten magma body.

\section{Pressure (depth)}

The pressure (depth) conditions of the LAPs were constrained using Rhyolite-MELTS (Gualda et al., 2012). For simplicity, we assumed the water content of the magma to be $3.0 \mathrm{wt} \%$, and used the major element composition of the youngest lava flow from Ontake volcano (OT16; $60.4 \mathrm{wt} \% \mathrm{SiO}_{2}$ ) and assumed that all the minerals crystallized from OT16. Pressures (depths) of the LAPs were estimated by comparing the independently obtained magmatic temperatures and petrological observations, such as the amount of quartz and melt $\mathrm{K}_{2} \mathrm{O}$ content, with the rhyolite-MELTS contour diagrams (Fig. 13). For example, the amount of quartz (in wt $\%$ ) was obtained for each temperature, pressure, water, and carbon dioxide content, and oxygen fugacity step. We summarized this information as a series of contour lines on a T-P plane (Fig. 13; Online Resource 3). The coexistence of quartz and orthoclase in the crystalline ash particles (Fig. 6(b)) restricts the P-T conditions of the magma to the colored area shown in Fig. 13(a), where quartz and orthoclase are stable. The corroded nature of quartz in the glassy ash particles (Fig. 6(a)) constrains the $\mathrm{P}-\mathrm{T}$ conditions as being outside the stability field of quartz shown in Fig. 13(a). The observed $\mathrm{K}_{2} \mathrm{O}$ and $\mathrm{SiO}_{2}$ contents of melt inclusions (Fig. 8(h)) constrain the P-T conditions as those that satisfy $>75 \mathrm{wt} \% \mathrm{SiO}_{2}$ (Fig. 13(b); $800{ }^{\circ} \mathrm{C}$ and $100-300 \mathrm{MPa}$ ) and $5-7 \mathrm{wt} \% \mathrm{~K}_{2} \mathrm{O}$ (Fig. 13(e); pink region; $750{ }^{\circ} \mathrm{C}$ and $50-300 \mathrm{MPa} ; 700-850{ }^{\circ} \mathrm{C}$ and $50 \mathrm{MPa}$ ). The bimodal composition of plagioclase (Fig. 10) suggests a cooling path through 1000 to $750{ }^{\circ} \mathrm{C}$ at a pressure of $100 \mathrm{MPa}$ (Fig. 13(c)). However, the higher An plagioclase could have crystallized from a less differentiated magma. The areas in the P-T diagram of the same An composition shrink at higher temperatures in Fig. 13(d), in the case of fractional crystallization, as compared with Fig. 13(c) where all phases are in equilibrium. Calculated plagioclase An contents due to fractional crystallization are lower than those resulting from equilibrium crystallization because, during fractional crystallization, $\mathrm{Ca}$ in the melt is incorporated into the plagioclase crystal cores. In summary, the pressure (depth) of the source of the LAPs is estimated to be $50-100 \mathrm{MPa}(2-4 \mathrm{~km})$, and the estimated temperatures of the crystalline particles (Fig. 7(b)) are lower than those of the glassy particles (Fig. 6(b)). 

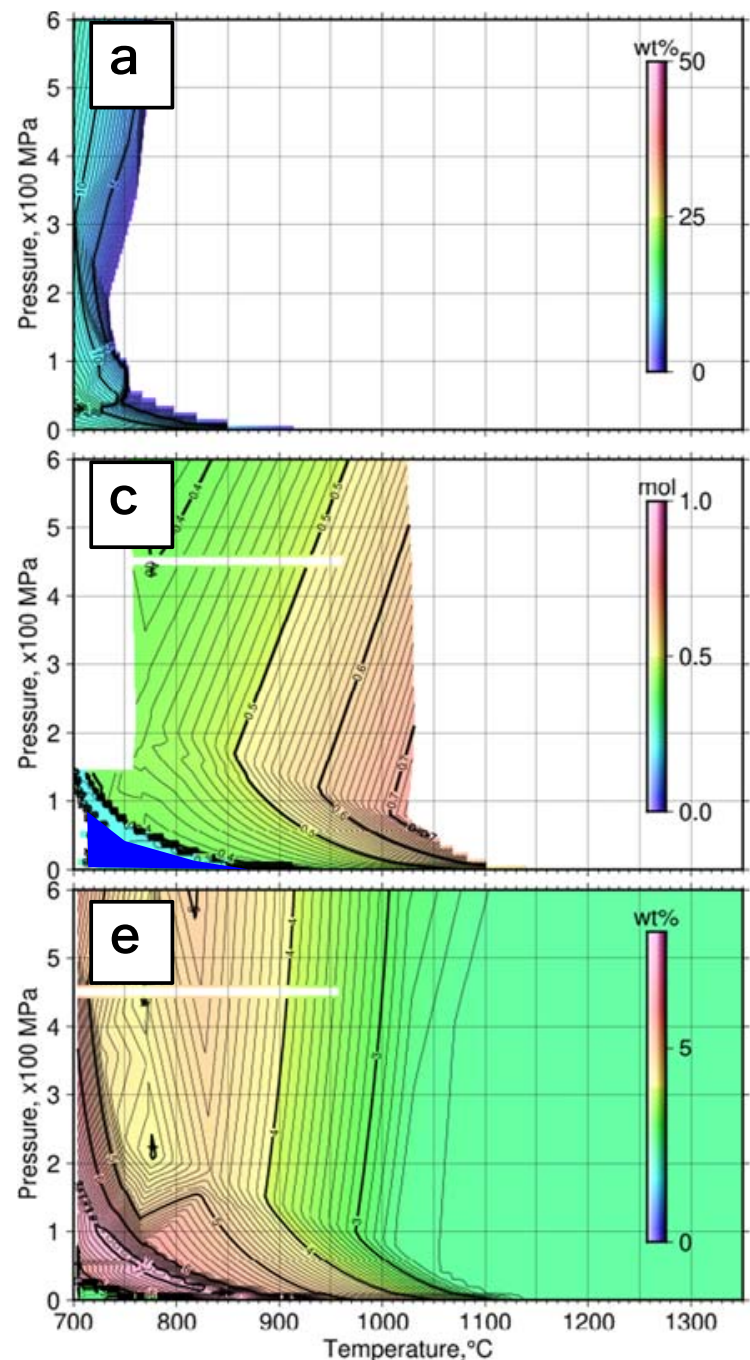

Fig. 13 Example of the results of a Rhyolite-MELTS (Gualda et al., 2012) computation. A set of contour diagrams on a T-P plane are shown for the case of the bulk composition of OT16 (Fig. 8). OT16 is San-no-ike lava from Yamada and Kobayashi (1988), which is the most silicic erupted magma in the earlier eruptive stage of the Ontake volcano, with water content and oxygen fugacity of $3 \mathrm{wt} \% \mathrm{H}_{2} \mathrm{O}$ and $\mathrm{FMQ}+2 \log$ units $(\simeq \mathrm{NNO}+1)$, respectively. Changes in water content have a negligible

\section{Melt fraction}

The melt fraction of hydrous magma depends on temperature and pressure. In general, the lower the temperature, the lower the melt fraction. In addition, the lower the pressure, the lower the melt fraction at 100-200 MPa (Fig. 13(f)). Temperatures and pressures of $\mathrm{Gl}$ were estimated to be $700-1300^{\circ} \mathrm{C}$ and 50-100 MPa, and for Xtn, the temperatures were $<700{ }^{\circ} \mathrm{C}$ with pressures of 50-100 $\mathrm{MPa}$. At these temperature and pressure conditions, the melt fraction of OT16 (Fig. 8; San-no-ike lava; Yamada and Kobayashi (1988)) is estimated to be < $10 \mathrm{wt} \%$ (Fig. 13(e); $<700{ }^{\circ} \mathrm{C}$ ) for Xtn and $60 \mathrm{wt} \%$ for Gls (Fig. 13(f); $\sim 900^{\circ} \mathrm{C}$ ). These estimated melt fractions are consistent with those observed in Xtn and Gls.

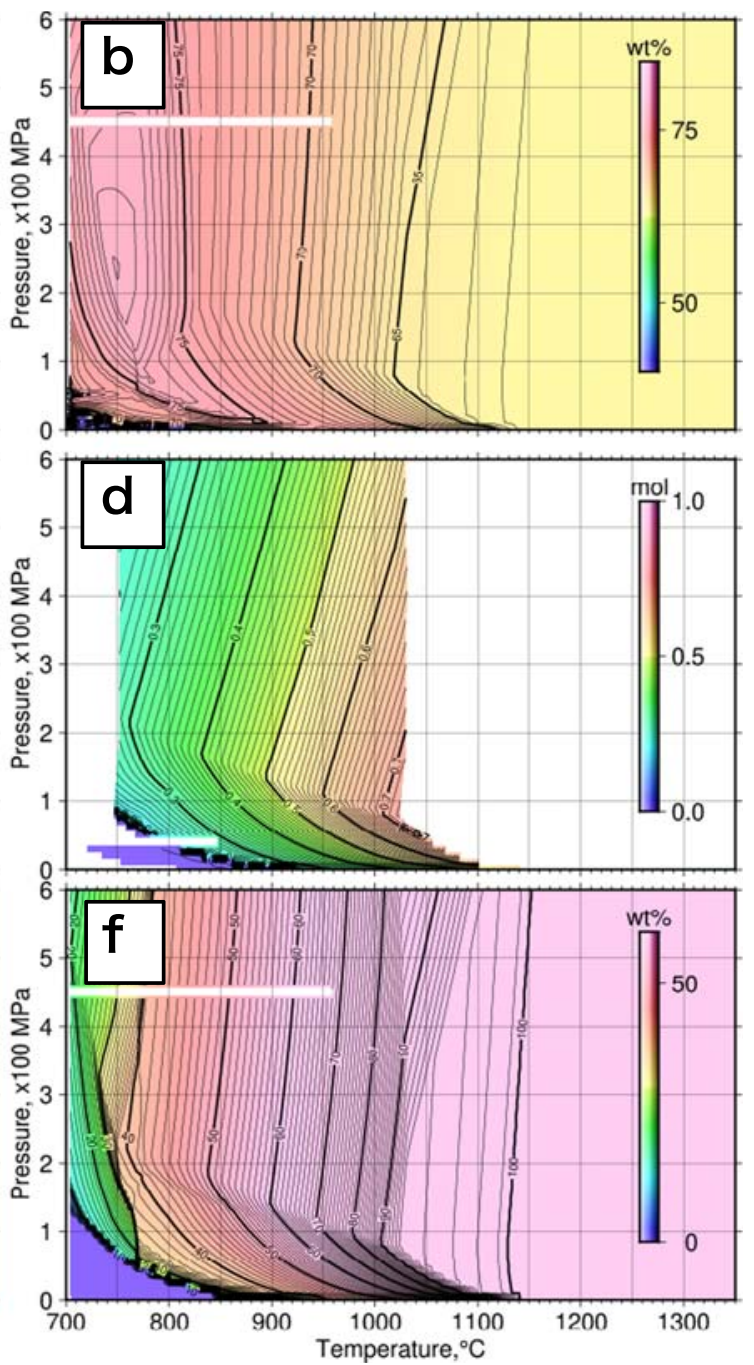

effect on the variables when the pressure is below $200 \mathrm{MPa}$ because the magma is water-saturated. The variables plotted are as follows. (a) Amount of quartz (wt\%). (b) Melt $\mathrm{SiO}_{2}$ content (wt\%). (c) Anorthite molar content $(0-1)$ of plagioclase. The blue-filled area represents the $\mathrm{P}-\mathrm{T}$ conditions where orthoclase is stable. (d) Anorthite molar content $(0-1)$ of plagioclase (solids fractionated during MELTS calculations). (e) Melt $\mathrm{K}_{2} \mathrm{O}$ content (wt $\%$ ). (f) The amount of melt (wt $\%$ )

\section{Source of heat and magmatic gas in the 2014 eruption}

Geophysical and geochemical evidence suggests that hot pressurized fluid (or magma) exists about 5-12 km beneath Mount Ontake. The seismic-aseismic boundary of larger earthquakes $(M>6)$ is found at distances of about $10 \mathrm{~km}$ from the center of the volcano, suggesting the presence of higher heat flux and thinned seismogenic crustal layer near the volcano (Ito, 1993). Over-pressurized fluid reservoirs have also been identified at depths between 5 and $12 \mathrm{~km}$ below the southeast and east flanks of Mount Ontake (Terakawa et al., 2013). Finally, ${ }^{3} \mathrm{He} /{ }^{4} \mathrm{He}$ ratios of natural spring water at the most proximal site (Nigorigo) to the central cone of Ontake volcano were 
constant during November 1981 through June 2000 but then increased from June 2003 through November 2014 (Sano et al., 1998). The increase in ${ }^{3} \mathrm{He} /{ }^{4} \mathrm{He}$ was evident at the proximal site but was not measurable in the distal areas (Kagoshima et al., 2016). In addition, a high $\mathrm{SO}_{2}$ gas flux (> $2000 \mathrm{t} /$ day $\mathrm{SO}_{2}$ ) was observed immediately after the 2014 eruption (Mori et al., 2016). Moreover, geochemical observations imply the existence of high-temperature magmatic fluids at depth (Mori et al., 2016).

The estimated source depth of Gl and Xtn $(2-4 \mathrm{~km})$ is comparable with the depth of the hot pressurized fluid (magma) injected during the 2007 event. As such, we consider the over-pressurized fluid reservoir detected by Terakawa et al. (2013) to be a magma reservoir, rather than steam. Magma injection occurred during the 2007 event, but there was little or no inflation before the 2014 eruption (Yamaoka et al., 2016). For example, GNSS detected an intrusion event at a depth of $3 \mathrm{~km}$ beneath Mount Ontake in 2007 (Nakamichi et al., 2009), and the volume change during this event was $6 \times$ $10^{6} \mathrm{~m}^{3}$ (Takagi and Onizawa, 2016). A decrease in groundwater pressure was also observed $\sim 10 \mathrm{~km}$ southeast of the summit of Mount Ontake prior to the 2007 eruption, consistent with magmatic intrusion (Koizumi et al., 2016). Instead, in 2014, GNSS data indicated only a comparatively small volume of ground inflation of $0.38 \times 10^{6} \mathrm{~m}^{3}$, just $7 \mathrm{~min}$ prior to the eruption (Takagi and Onizawa, 2016).

A model for magmatically driven phreatic eruptions for Ontake's 2014 eruption by Stix and de Moor (2018) explained the elevated $\mathrm{SO}_{2}$ gas flux by a release of hightemperature gas from a magma emplaced at shallow levels since 2007, where the hydrothermal system and the magma are separated, and the material supplied from the magma to the hydrothermal system is volcanic gas, i.e., no magma input into the hydrothermal system.

On the other hand, our petrological observations support direct magmatic input into the hydrothermal system. We have shown the presence of a partially solidified (Xtn), but still molten (Gls), magma body that was intruded 2-4 km below the surface of Mount Ontake. The estimated source depth of Gl and Xtn $(2-4 \mathrm{~km})$ matches the independently estimated source depth of the hydrothermally altered zone of Mount Ontake $(<2-4 \mathrm{~km})$ (Minami et al., 2016). We estimate the volume of the intruded magma body to be equivalent to the observed volume change in 2007 (red square in Fig. 14). This magma may have supplied heat, and also supplied magmatic gas, to the surrounding hydrothermally altered zone since 2007. It takes some time to cool down a magma intrusion. With a thermal diffusion rate of $D=0.01 \mathrm{~cm}^{2} / \mathrm{s}$, the diffusion distance $(x=\sqrt{D t})$ for 7 years is only about $15 \mathrm{~m}$. It is thus not surprising that the magma injected (Fig. 14, a cube with a side of $180 \mathrm{~m}$ ), in 2007 , took 7 years to cool down to accumulate the magmatic volatiles via crystal fractionation and

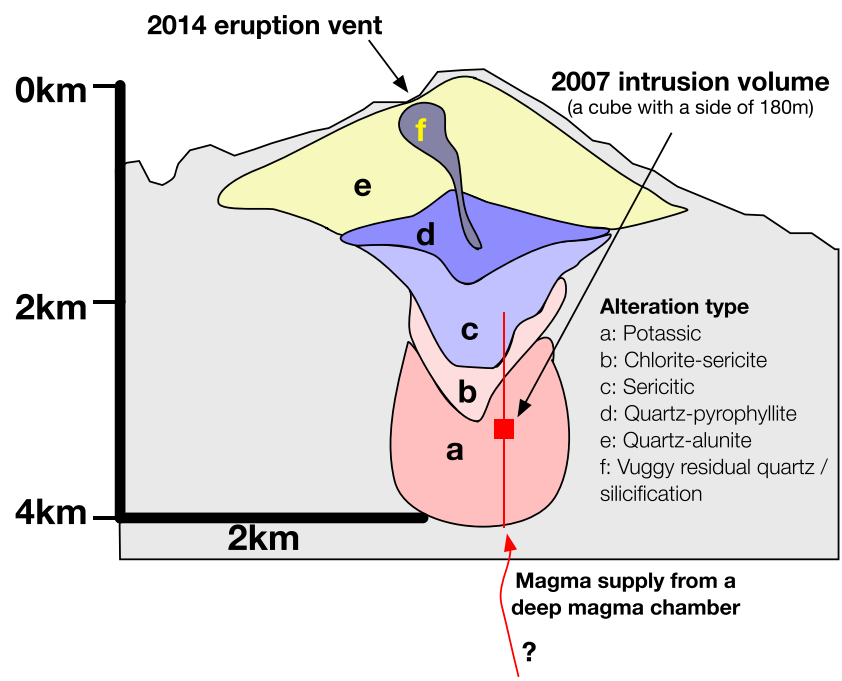

Fig. 14 Size and depth of the magma intrusion in 2007. Red square $=$ volume of the magma intrusion (total $6 \times 10^{6} \mathrm{~m}^{3}$; Takagi and Onizawa (2016)) based on a cube-shaped magma body with a side of $180 \mathrm{~m}$. Alteration zones underlying the edifice are from Fig. 5 of Minami et al. (2016) and are given with letter-labeled colors, as listed on the figure

eventually trigger the eruption in 2014. If this interpretation is correct, we have the key to (1) timing and scale of magma injection into the hydrothermal system from geophysical observations of crustal deformation, (2) the time scale of magma crystallization from thermal diffusion modeling, (3) timing of gas saturation from petrological modeling of the magma, and, thus, (4) provide a model that allows geophysical and geochemical observation to be placed in a framework that allows the buildup to phreatic eruptions at Ontake to be tracked.

\section{Conclusions}

We identified LAPs (i.e., potential magmatic particles) in volcanic ash from the 2014 Mount Ontake eruption, which was thought to be phreatic. The LAPs were almost solidified (Xtn) or still molten (Gls) magma just prior to the eruption, and were probably derived from magma intruded into a hydrothermally altered zone during 2007. This 2007 event may have supplied the heat and gas for the 2014 eruption.

This study, in line with several other recent studies on phreatic-like eruptions that report a trace amount of glasses that appear to be juvenile (Alvarado et al., 2016; Cashman and Hoblitt, 2004; Gaunt et al., 2016), raises the issue of whether or not such events should be called phreatomagmatic. However, long-term coupled geophysical and geochemical monitoring and modeling of volcanic crustal fluid fluxed, as done here, could enable the detection of shallow intrusions that are the heat source for later phreatic eruptions. This, in turn, will help mitigate future volcanic hazards. 
Open Access This article is licensed under a Creative Commons Attribution 4.0 International License, which permits use, sharing, adaptation, distribution and reproduction in any medium or format, as long as you give appropriate credit to the original author(s) and the source, provide a link to the Creative Commons licence, and indicate if changes were made. The images or other third party material in this article are included in the article's Creative Commons licence, unless indicated otherwise in a credit line to the material. If material is not included in the article's Creative Commons licence and your intended use is not permitted by statutory regulation or exceeds the permitted use, you will need to obtain permission directly from the copyright holder. To view a copy of this licence, visit http://creativecommons.org/licenses/by/4.0/.

\section{References}

Alvarado GE, Mele D, Dellino P, de Moor JM, Avard G (2016) Are the ashes from the latest eruptions (2010-2016) at Turrialba volcano (Costa Rica) related to phreatic or phreatomagmatic events? J Volcanol Geotherm Res 327:407-415

Asimow P, Ghiorso M (1998) Algorithmic modifications extending melts to calculate subsolidus phase relations. Am Mineral 83:1127-1131

Bacon CR, Hirschmann MM (1988) Mg/Mn partitioning as a test for equilibrium between coexisting Fe-Ti oxides. Am Mineral 73(12):57-61

Barberi F, Cioni R, Rosi M, Santacroce R, Sbrana A, Vecci R (1989) Magmatic and phreatomagmatic phases in explosive eruptions of Vesuvius as deduced by grain-size and component analysis of the pyroclastic deposits. J Volcanol Geotherm Res 38(3):287-307. https://doi.org/10.1016/0377-0273(89)90044-9 URL http://www. sciencedirect.com/science/article/pii/0377027389900449

Barberi F, Bertagini A, Landi P, Principe C (1992) A review on phreatic eruptions and their precursors. J Volcanol Geotherm Res 52:231246

Browne P, Lawless J (2001) Characteristics of hydrothermal eruptions, with examples from New Zealand and elsewhere. Earth Sci Rev 52: 299-331

Bruce V (2002) No apparent danger: the true story of volcanic disaster at Galeras and Nevado Del Ruiz. HarperCollins URL https://books. google.co.jp/books?id=abwWlwEACAAJ

Cas R, Wright J (1987) Volcanic successions. ISBN 041244640 5, Chapman \& Hall

Cashman K, Hoblitt R (2004) Magmatic precursors to the 18 May 1980 eruption of Mount St. Helens, USA. Geology 32(2):141-144. https://doi.org/10.1130/G20078.1

Erfurt-Cooper P, Cooper M (eds) (2010) Volcano and geothermal tourism: sustainable geo-resources for leisure and recreation. Routledge

Fischer RV, Waters AC (1970) Base surge bed forms in maar volcanoes. Amer J Sci 268:157-180

Gaunt HE, Bernard B, Hidalgo S, Proaño A, Wright H, Mothes P, Criollo E, Kueppers U (2016) Juvenile magma recognition and eruptive dynamics inferred from the analysis of ash time series: the 2015 reawakening of Cotopaxi volcano. J Volcanol Geotherm Res 328: $1-13$

Germanovich LN, Lowell RP (1995) The mechanism of phreatic eruptions. J Geophys Res 100(B5):8417-8434

Ghiorso MS, Evans BW (2008) Thermodynamics of rhombohedral oxide solid solutions and a revision of the fe-ti two-oxide geothermometer and oxygen-barometer. Amer J Sci 308(9):957-1039

Gill J (1981) Orogenic andesite and plate tectonics. Springer-Verlag, New York

Gualda GAR, Ghiorso MS, Lemons RV, Carley TL (2012) RhyoliteMELTS: a modified calibration of MELTS optimized for silica-rich, fluid-bearing magmatic systems. J Petrol 53(5):875-890
Hamada M, Fujii T (2007) $\mathrm{H}_{2} \mathrm{O}$-rich island arc low-K tholeiite magma inferred from $\mathrm{Ca}$-rich plagioclase-melt inclusion equilibria. Geochem J 41:437-461

Hamasaki S (2010) Quarternary volcanic-related acid hydrothermal alteration in the Ugusu silica stone deposit, western Izu Peninsula, central Japan: geology and alteration. Resour Geol 59:153-169

Hedenquist J, Matsuhisa Y, Izawa E, White N, Giggenbach W, Aoki M (1994) Geology, geochemistry, and origin of high sulfidation $\mathrm{Cu}-\mathrm{Au}$ mineralization in the Nansatsu district, Japan. Econ Geol 89:1-30

Hedenquist JW, Henley RW (1985) Hydrothermal eruptions in the waiotapu geothermal system, New Zealand; their origin, associated breccias, and relation to precious metal mineralization. Econ Geol 80(6):1640-1668

Henley R, Ellis A (1983a) Geothermal systems, ancient and modern: a geochemical review. Earth Sci Rev 19:1-50

Henley R, Ellis A (1983b) Geothermal systems ancient and modern: a geochemical review. Earth Sci Rev 19(1):1-50

Ikehata K, Maruoka T (2016) Sulfur isotopic characteristics of volcanic products from the September 2014 Mount Ontake eruption, Japan. Earth Planet Space 68(116):1-7

Ito K (1993) Cutoff depth of seismicity and large earthquakes near active volcanoes in Japan. Tectonophysics 217:11-21

Izawa E (1990) The Hishikari gold deposit: high-grade epithermal veins in Quaternary volcanics of southern Kyushu Japan. J Geochem Explor 36:1-56

JMA (1991) Ontake volcano. Bull Volcanol Soc Japan 36:385 (in Japanese)

JMA (2013) National catalogue of the active volcanoes in Japan, vol 4. Japan Meteorological Business Support Center

JMA (2014) Rep. coording. committee on prediction of volcanic eruption. 130(1)

Kagoshima T, Sano Y, Takahata N, Ishida A, Tomonaga Y, Roulleau E, Pinti DL, Fischer TP, Lan T, Nishio Y, Tsunogai U, Guo Z (2016) Spatial and temporal variations of gas geochemistry at Mt. Ontake, Japan. J Volcanol Geotherm Res 325:179-188

Kaneko T, Maeno F, Nakada S (2016) 2014 Mount Ontake eruption: characteristics of the phreatic eruption as inferred from aerial observations. Earth Planet Space 68(72):1-11

Kato A, Terakawa T, Yamanaka Y, Maeda Y, Horikawa S, Kenjiro M, Okuda T (2015) Preparatory and precursory process leading up to the 2014 phreatic eruption of Mount Ontake, Japan. Earth Planet Space 67(111):1-13. https://doi.org/10.1186/s40,623-015-0288-x

Kioka H, Furuyama K, Miyake Y, Sakai I, Nagao K, Ikemoto M, Noiri H, Oda K (1998) K-Ar chronology of the Middle Pleistocene lavas at Ontake Volcano, central Japan. Earth Sci (Chikyu Kagaku) 52:464 474 (in Japanese)

Koizumi N, Sato T, Kitagawa Y, Ochi T (2016) Groundwater pressure changes and crustal deformation before and after the 2007 and 2014 eruptions of Mt. Ontake. Earth, Planets Space 68(48):1-6

Kusakabe M, Mizutani Y, Kometani M (1982) A preliminary stable isotope study of volcanic ashes discharged by the 1979 eruption of Ontake volcano, Nagano, Japan. Bull Volcanol 45(3):203-209

Lloyd E (1959) The hot springs and hydrothermal eruptions of Waiotapu. N Z J Geol Geophys 2(1):141-176

Lorenz V (1987) Phreatomagmatism and its relevance. Chem Geol 62: $149-156$

MacKenzie W, Donaldson C, Guilford C (1982) Atlas of igneous rocks and their textures. Longman Scientific and Technical

Maeda Y, Kato A, Terakawa T, Yamanaka Y, Horikawa S, Matsuhiro K, Okuda T (2015) Source mechanism of a VLP event immediately before the 2014 eruption of Mt. Ontake, Japan. Earth Planet Space 67(187):1-7

Maeno F, Nakada S, Oikawa T, Yoshimoto M, Komori J, Isuizuka Y, Takeshita Y, Shimano T, Kaneko T, Nagai M (2016) Reconstruction of a phreatic eruption on 27 September 2014 at 
Ontake volcano, central Japan, based on proximal pyroclastic density current and fallout deposits. Earth Planet Space 68(82):1-20

Marini L, Principe C, Chiodini G, Cioni R, Fytikas M, Marinelli G (1993) Hydrothermal eruptions of Nisyros (Dodecanese, Greece). Pase events and present hazard. J Volcanol Geotherm Res 56:71-94

Mastin LG (1995) Thermodynamics of gas and steam-blast eruptions. Bull Volcanol 57:85-98

Matsumoto A, Kobayashi T (1995) K-Ar age determination of late Quaternary volcanic rocks using the "mass fractionation correction procedure": application to the Younger Ontake Volcano, central Japan. Chem Geol 125:123-135

Matsumoto A, Kobayashi T (1999) K-Ar ages of the older Ontake volcanic products, Ontake volcano, central Japan: reappraisal of the volcanic history based on the radiometric data. Bull Volcanol Soc Japan 44:1-12 (in Japanese with English abstract)

Mattox TN, Mangan MT (1997) Littoral hydrovolcanic explosions: a case study of lava-seawater interaction at Kilauea volcano. J Volcanol Geotherm Res 75:1-17

Mayer K, Scheu B, Gilg HA, Heap MJ, Kennedy BM, Lavallée Y, Letham-Brake M, Dingwell DB (2015) Experimental constraints on phreatic eruption processes at Whakaari (White Island volcano). J Volcanol Geotherm Res 302:150-162

Mayer K, Scheu B, Montanaro C, Yilmaz TI, Isaia R, Aßbichler D, Dingwell DB (2016) Hydrothermal alteration of surficial rocks at Solfatara (Campi Flegrei): petrophysical properties and implications for phreatic eruption processes. J Volcanol Geotherm Res 320:128143

McPhie J, Walker GP, Christiansen RL (1990) Phreatomagmatic and phreatic fall and surge deposits from explosions at Kilauea volcano, Hawaii, 1970 A.D.: Kanakakoi Ash Member. Bull Volcanol 52: 334-354

Minami Y, Imura T, Hayashi S, Ohba T (2016) Mineralogical study on volcanic ash of the eruption on September 27, 2014 at Ontake volcano, central Japan: correlation with porphyry copper systems. Earth Planet Space 68(67):1-11

Miyagi I, Kita NT, Morishita Y (2017) The geochemical and petrological characteristics of prenatal caldera volcano: a case of the newly formed small dacitic caldera, Hijiori, Northeast Japan. Contrib Mineral Petrol 172(79). https://doi.org/10.1007/s00410-017-13918): $1-17$

Miyaoka K, Takagi A (2016) Detection of crustal deformation prior to the 2014 Mt. Ontake eruption by the stacking method. Earth Planet Space 68(60):1-8

Montanaro C, Scheu B, Mayer K, Orsi G, Moretti R, Isaia R, Dingwell DB (2016) Experimental investigations on the explosivity of steamdriven eruptions: a case study of Solfatara volcano (Campi Flegrei). J Geophys Res 121:7996-8014. https://doi.org/10.1002/ 2016JB013,273

de Moor J, Aiuppa A, Pacheco J, Avard G, Kern C, Liuzzo M, Martínez M, Giudice G, Fischer T (2016) Short-period volcanic gas precursors to phreatic eruptions: insights from Poás volcano, Costa Rica. Earth Planet Sci Lett 442:218-227. https://doi.org/10.1016/j.epsl. 2016.02.056

Mori T, Hashimoto T, Terada A, Yoshimoto M, Kazahaya R, Shinohara H, Tanaka R (2016) Volcanic plume measurements using a UAV for the 2014 Mt. Ontake eruption. Earth Planet Space 68(49):1-18

Nakamichi H, Kumagai H, Nakano M, Okubo M, Kimata F, Ito Y, Obara K (2009) Source mechanism of a very-long-period event at Mt Ontake, central Japan: response of a hydrothermal system to magma intrusion beneath the summit. J Volcanol Geotherm Res 187:167177

Nakamura M (1995) Continous mixing of crystal mush and replenished magma in the ongoing Unzen eruption. Geology 23:807-810

Nakano S, Oikawa T, Yamasaki S, Kawanabe Y (2014) Eruption of Ontakesan in September, 2014. GSJ Chisitsu News 3(389-292 (in Japanese))
Ogiso M, Matsubayashi H, Yamamoto T (2015) Descent of tremor source locations before the 2014 phreatic eruption of Ontake volcano, Japan. Earth Planet Space 67(206):1-12

Oh M, Corradini M (1987) A propagation/expansion model for large scale vapor explosions. Nucl Sci Eng (United States) 95:3

Ohba T, Taniguchi H, Miyamoto T, Hayashi S, Hasenaka T (2007) Mud plumbing system of an isolated phreatic eruption at Akita Yakeyama volcano, northern Honshu, Japan. J Volcanol Geotherm Res 161:3546

Oikawa T (2008) Reinvestigation of the historical eruption and fumarolic activity records at Ontake volcano, central Japan. Misunderstanding reports about the $774 \mathrm{AD}$ and $1892 \mathrm{AD}$ eruptions. Bull Geol Surv Japan 59:203-210 (in Japanese with English abstract)

Oikawa T, Suzuki Y, Chiba T (2014) Eruptions of Ontake-san: history and 2014 eruption. Kagaku 84:1218-1225 (in Japanese)

Oikawa T, Yamaoka K, Yoshimoto M, Nakada S, Takeshita Y, Maeno F, Ishizuka Y, Komori J, Shimano T, Nakano S (2015) The 2014 eruption of Ontake volcano, Central Japan. Bull Volcanol Soc Japan 60: 411-415 (in Japanese)

Oikawa T, Yoshimoto M, Nakada S, Maeno F, Komori J, Shimano T, Takeshita Y, Ishizuka Y, Ishimine Y (2016) Reconstruction of the 2014 eruption sequence of Ontake volcano from recorded images and interviews. Earth Planet Space 68(79):1-13

Ossaka J (2003) Clay minerals contained in volcanic ejecta and their correlation with volcanic activities in Japan. Bull Volcanol Soc Japan 48(1):43-61 (in Japanese with English abstract)

Ossaka J, T O, Sakai H, Hirabayashi J (1983) Geochemical study on the volcanic activity of kiso-ontake volcano, after the 1979 eruption. Bull Volcanol Soc Japan 28:59-74 (in Japanese with English abstract)

Papale P, Dobran F (1993) Modeling of the ascent of magma during the plinian eruption of Vesuvius in A.D. 79. J Volcanol Geotherm Res 58:101-132

Reyers A (1990) Petrology of Philippine geothermal systems and the application of alteration mineralogy to their assessment. J Volcanol Geotherm Res 43:279-309

Sack RO, Carmichael ISE, RIvers M, Ghiorso MS (1980) Ferric- ferrous equilibria in natural silicate liquids at 1 bar. Contrib Mineral Petrol 75:369-376

Sano Y, Nishio Y, Sasaki S, Gamo T, Nagao K (1998) Helium and carbon isotope systematics at Ontake volcano, Japan. J Geophys Res 103(B10):23,863-23,873

Sasaki H, Chiba T, Kishimoto H, Naruke S (2016) Characteristics of the syneruptive-spouted type lahar generated by the September 2014 eruption of Mount Ontake, Japan. Earth Planet Space 68(141):1-11

Sato E, Shinbori T, Fukui K, Ishii K, Takagi A (2017) The eruption cloud echo from Mt. Ontake on September 27, 2014 observed by weather radar network. Rep Coordinat Commit Predict Volc Erup 119:76-81 (in Japanese with English figure captions)

Schmincke HU (2004) Volcanism. Springer-Verlag

Sheridan MF, Wohletz KH (1981) Hydrovolcanic explosions: the systematics of water-pyroclast equilibration. Science 212(4501):13871389

Sheridan MF, Wohletz KH (1983) Hydrovolcanism: basic considerations and review. J Volcanol Geotherm Res 17(1):1-29 explosive Volcanism

Siebert L, Glicken H, Ui T (1987) Volcanic hazards from Bezymiannyand Bandai-type eruptions. Bull Volcanol 49:435-459

Sigurdsson H, Cashdollar S, Sparks SRJ (1982) The eruption of Vesuvius in A. D. 79: reconstruction from historical and volcanological evidence. Am J Archaeol 86(1):39-51

Soya T, Kondo Y, Shimosaka Y (1980) Mt. ontake-san 1979 eruption. Chisitsu news 306:6-13 (in Japanese)

Stix J, de Moor JM (2018) Understanding and forecasting phreatic eruptions driven by magmatic degassing. Earth, Planets Space 70(1):83. https://doi.org/10.1186/s40623-018-0855-Z 
Sugiura T, Sugiura R, Mizutani Y, Kusakabe M (1983) Geochemistry of volcanic ashes, thermal waters and gases ejected during the 1979 eruption of Ontake volcano, Japan. Bull Volcanol Soc Jpn 25:231244 (in Japanese with English abstract)

Takagi A, Onizawa S (2016) Shallow pressure sources associated with the 2007 and 2014 phreatic eruptions of Mt. Ontake, Japan. Earth Planet Space 68(135):1-9

Takarada S, Oikawa T, Furukawa R, Hoshizumi H, Itoh J, Geshi N, Miyagi I (2016) Estimation of total discharged mass from the phreatic eruption of Ontake volcano, central Japan, on September 27, 2014. Earth Planet Space 68(1):1-9. https://doi.org/10.1186/ s40623-016-0511-4

Takeshita Y (2004) Volcanic history of the middle Pleistocene older Ontake volcano, Central Japan. Inferences from tephrostratigraphy and petrography. J Geol Soc Japan 110(3):158-184 (in Japanese with English abstract and figure captions)

Takeshita Y, Kiryu K, Hanai Y, Kitazawa N, Kawakami A (2017) Ash fall distribution of the 27 September 2014 eruption at Ontake volcano, central Japan, based on questionnaire survey. Jour Geol Soc Japan 123(5):291-307 (in Japanese with English abstract)

Terakawa T, Yamanaka Y, Nakamichi H, Watanabe T, Yamazaki F, Horikawa S, Okuda T (2013) Effects of pore fluid pressure and tectonic stress on diverse seismic activities around the Mt. Ontake volcano, central Japan. Tectonophysics 608:138-148

Tsunematsu K, Ishimine Y, Kaneko T, Yoshimoto M, Fujii T, Yamaoka K (2016) Estimation of ballistic block landing energy during 2014 Mount Ontake eruption. Earth Planet Space 68(88):1-11

Venezky DY, Rutherford MJ (1999) Petrology and Fe-Ti oxide reequilibration of the 1991 Mount Unzen mixed magma. J Volcanol Geotherm Res 89:213-230
Wall L, Schwartz RL (1991) Programming Perl. A nutshell handbook in a nutshell series UNIX programming, O'Reilly \& Associates

Wessel P, Smith W (1998) New, improved version of generic mapping tools released. EOS Trans Amer Geophys U 79(47):579

White JD (1996) Impure coolants and interaction dynamics of phreatomagmatic eruptions. J Volcanol Geotherm Res 74:155-170

White JD, Valentine GA (2016) Magmatic versus phreatomagmatic fragmentation: absence of evidence is not evidence of absence. Geosphere 12(5):1478-1488. https://doi.org/10.1130/GES01337.1

Wohletz KH (1986) Explosive magma-water interactions: thermodynamics, explosion mechanisms, and field studies. Bull Volcanol 48:245264

Yamada N, Kobayashi T (1988) Geology of the Ontakesan. Geological Sheet Map at 1:50,000, Geological Survey of Japan, p 136p (in Japanese with English abstract 9p)

Yamamoto T (2014) The pyroclastic density currents generated by the September 27, 2014 phreatic eruption of Ontake volcano, Japan. Bull Geol Surv Japan 65:117-127 (in Japanese with English abstract)

Yamamoto T, Soya T, Suto S, Uto K, Takada A, Sakaguchi K, Ono K (1991) The 1989 submarine eruption off eastern Izu Peninsula, Japan: ejecta and eruption mechanisms. Bull Volcanol 53:301-308

Yamaoka K, Geshi N, Hashimoto T, Ingebritsen S, Oikawa T (2016) Special issue "the phreatic eruption of Mt. Ontake volcano in 2014”. Earth, Planets Space 68(175). https://doi.org/10.1186/ s40,623-016-0548-4

Zimanowski B, Frohlich G, Lorenz V (1991) Quantitative experiments on phreatomagmatic explosions. J Volcanol Geotherm Res 48(3-4): 341-358 